\title{
Water footprint analysis of temporary crops produced in São Carlos (SP), Brazil
}

\section{Análise da pegada hídrica das culturas temporárias produzidas no município de São Carlos/SP}

\author{
Alan Reis ${ }^{1}$ (D), Alessandra Campos dos Santos ${ }^{1}$ (D), Jamil Alexandre Ayach Anache ${ }^{2}$ (D), Eduardo Mario Mendiondo ${ }^{1}$ (D) \& \\ Edson Cezar Wendland ${ }^{1}$
}

${ }^{1}$ Universidade de São Paulo, São Carlos, SP, Brasil

${ }^{2}$ Universidade Federal do Mato Grosso do Sul, Campo Grande, MS, Brasil

E-mails: alanreis.ar@gmail.com (AR), alecampos@usp.br (ACS), anache.jamil@gmail.com (JAAA), emm@sc.usp.br (EMM),ew@sc.usp.br (ECW)

Received: January 31, 2020 - Revised: April 30, 2020 - Accepted: May 12, 2020

\begin{abstract}
This paper aims to evaluate the water footprint (WF) of temporary crops produced in the municipality of São Carlos, Brazil, between 2004 and 2017. The WF calculation was developed following the Water Footprint Network approach (WFN) and using CROPWAT model. The results were compared with the world averages and other studies that analyzed the same crops. We applied statistical tests to verify data behavior over the years and calculated correlation coefficients between WF components and crop yields. The results indicated low values of total WF for sugarcane (total average of $166.2 \mathrm{~m}^{3} \mathrm{ton}^{-1}$ ) and tomato (total average of $97.2 \mathrm{~m}^{3}$ ton ${ }^{-1}$ ), while rice (total average of $5212.4 \mathrm{~m}^{3}$ ton $^{-1}$ ) and groundnut (total average of $3865.8 \mathrm{~m}^{3}$ ton $^{-1}$ ) showed the opposite. In general, WF components do not follow a monotonic trend, a normal distribution can be assumed and there is a statistically significant difference when comparing our findings with global mean values. These results ratify the importance of local WF studies, especially in Brazil, considering its importance in global agricultural market and the respective use of water resources.
\end{abstract}

Keywords: Water security; Agricultural production; Water scarcity; Water use.

\section{RESUMO}

Este trabalho visa avaliar a pegada hídrica ( $\mathrm{PH}$ ) das culturas temporárias produzidas no munícipio de São Carlos/SP, no período entre 2004 e 2017. O cálculo da pegada hídrica foi desenvolvido seguindo a metodologia da Water Footprint Newtwork (WFN) e o modelo CROPWAT. Os resultados foram comparados com as médias mundiais e outros estudos que analisaram as mesmas culturas. Foram aplicados alguns testes estatísticos para verificar o comportamento dos dados ao longo do tempo e calculou-se os coeficientes de correlação entre as componentes de pegada hídrica e as produtividades de cada cultura. Os resultados indicam baixos valores de PH total para a cana-de-açúcar (valor médio total de $166.2 \mathrm{~m}^{3}$ ton $^{-1}$ ) e tomate (valor médio total de $97.2 \mathrm{~m}^{3}$ ton $^{-1}$ ), enquanto arroz (valor médio total de $5212.4 \mathrm{~m}^{3}$ ton $^{-1}$ ) e amendoim (valor médio total de $3865.8 \mathrm{~m}^{3}$ ton $^{-1}$ ) apresentam valores elevados. Em geral, os componentes da PH não seguem uma tendência monotônica; uma distribuição normal dos dados pode ser assumida ao longo dos anos; e existe uma diferença estatisticamente significante entre quando comparando os resultados calculados e os valores médios globais. Tais resultados ratificam a importância da realização de estudos locais de pegada hídrica, especialmente no Brasil, considerando sua importância no mercado agrícola global e o respectivo uso da água para tal fim.

Palavras-chave: Segurança hídrica; Produção agrícola; Escassez de água; Uso da água. 


\section{INTRODUCTION}

Freshwater use is increasing worldwide because of population growth and economic demands, and many regions around the globe are already experiencing frequent or severe water shortages. According to the Organisation for Economic Co-operation and Development (2019), 70\% of the planet's freshwater is used by agriculture. This economic activity exerts pressure on water resources as a result of human demand for food. It is important to understand how water resources are incorporated into agriculture, both in terms of direct consumption and pollution generation. One way to check this is by determining the water footprint (WF). This indicator aims to determine the water volume used, directly and indirectly, in the production chain of a given product (Hoekstra, 2003; Hoekstra et al., 2011).

The WF is usually divided into three components: the green $\left(\mathrm{WF}_{\text {green }}\right)$, blue $\left(\mathrm{WF}_{\text {blue }}\right)$ and gray water footprint $\left(\mathrm{WF}_{\text {gray }}\right)$, accounted considering the indirect and direct use. In the context of agricultural production, indirect use refers to water consumed in complementary products used during the crop growing, as seeds, fertilizers, pesticides, sowing and harvesting operations, and others, which were not accounted here. Direct use refers to water consumed by the plant itself, during its growing, which we determined in this study. Each component of WF refers to:

- $\mathrm{WF}_{\text {green }}$ refers to the water consumption resulting from rainfall, which does not generate runoff, and is stored or remains temporarily in the soil or the vegetation. (Hoekstra et al., 2011);

- $\mathrm{WF}_{\text {blue }}$ refers to groundwater or surface freshwater consumption, evaporated and incorporated into the product, during production. (Hoekstra et al., 2011);

- $\mathrm{WF}_{\text {gray }}$ is the volume of water needed to assimilate the pollutant load generated by the activity, for example, fertilizers and pesticides (Hoekstra et al., 2011).

Mekonnen \& Hoekstra (2011) were the pioneers in determining the water footprint for agricultural production at a global level. The authors analyzed 126 crops between 1996 and 2005, using a high-resolution approach. However, the uncertainty involved in a global study, without the appropriate geographical specifications, have encouraged regional and local studies in recent years (Lovarelli et al., 2016). Vanham (2013), Mekonnen et al. (2015), Zhang et al. (2016) and Hoekstra \& Mekonnen (2016) conducted regional and country studies and obtained agricultural water footprint values to verify how commodity-exporting countries can be considered virtual water exporters, sending water resources embedded in exported agricultural products. In Brazil, Silva et al. (2016) determined the water footprint of agricultural and livestock activities for all states, concluding that Brazil is a virtual water exporter. Scarpare et al. (2016) calculated sugarcane water footprint in the Tietê/Jacaré watershed in São Paulo state, where high production of this crop occurs. To the best of our knowledge, this study represents a unique sub-national water footprint assessment in Brazil.

At the municipal level, there are no studies that assessed the water footprint in Brazil. The main reason is the lack of local climate data in most municipalities. Another missing analysis is the evaluation of the temporal evolution of the agricultural water footprint, which can allow to observe the annual values of this indicator and to identify possible causes of the variation, linked to climate, productivity or crop management.

This study aimed to evaluate the water used by temporary crops produced in the municipality of São Carlos, São Paulo state (SP), Brazil, through direct water footprint estimation between 2004 and 2017. Besides, this study may become a reference for municipalities with similar climatic characteristics and similar agricultural production, in terms of crops and yields, especially in tropical areas (Burt \& McDonnell, 2015).

\section{MATERIAL AND METHODS}

\section{Study area}

This study was conducted in the municipality of São Carlos (Latitude 22 $2^{\circ}$ ' 55' S, Longitude 47 53' 28” W, altitude: $854 \mathrm{~m}$ ), situated in São Paulo (SP) state, Brazil, (Figure 1). This municipality has a humid subtropical climate (Cwa, Köppen), with a hot and wet summer and a dry winter (Alvares et al., 2014). The average annual rainfall and temperature are $1486 \mathrm{~mm} \mathrm{yr}^{-1}$ and $19{ }^{\circ} \mathrm{C}$, respectively (Cabrera et al., 2016). Cerrado (Brazilian savanna) is the predominant biome (São Carlos, 2019).

São Carlos has a total area of $1,136.93 \mathrm{~km}^{2}$, divided in $67.25 \mathrm{~km}^{2}$ of urban area and $1,069.68 \mathrm{~km}^{2}$ of rural use. Approximately $730 \mathrm{~km}^{2}$ of the rural area is occupied by farms, where agricultural and livestock activities are developed. Forestry and preservation areas are also observed in the municipality area (Instituto Brasileiro de Geografia e Estatística, 2018).

The object of study is the temporary crops cultivated in the rural areas of São Carlos. Temporary crops are those which are both sown and harvested during the same agricultural year, sometimes more than once. In São Carlos, we found sugarcane, maize, soybean, tomato, cassava, rice, beans, and groundnut as temporary crops. Only temporary crops were evaluated because of their predominance, ranging from $77.98\left(263.66 \mathrm{~km}^{2}\right)$ to $91.84 \%$ $\left(383.25 \mathrm{~km}^{2}\right)$ of the planted area. Permanent crops occupy the remaining fields (Instituto Brasileiro de Geografia e Estatística, 2018). Table 1 shows the planted area of the crops analyzed in this study and the occupation rate, considering the total area used for temporary crops and the municipality area.

\section{Water footprint calculation}

The direct water footprint of crops was calculated following the Water Footprint Assessment Manual, (Hoekstra et al., 2011). The total water footprint of the crops is the sum of three components: blue, green and gray water footprint $\left(\mathrm{WF}_{\text {blue }}, \mathrm{WF}_{\text {green }}\right.$, and $\left.\mathrm{WF}_{\text {gray }}\right)$, as shown in Equations 1, 2 and 3, respectively.

$$
\begin{aligned}
& W F_{\text {blue }}=\frac{C W U_{\text {blue }}}{Y} \\
& W F_{\text {green }}=\frac{C W U_{\text {green }}}{Y} \\
& W F_{\text {gray }}=\frac{(\alpha \times A R) /\left(c_{\text {máx }}-c_{\text {nat }}\right)}{Y}
\end{aligned}
$$



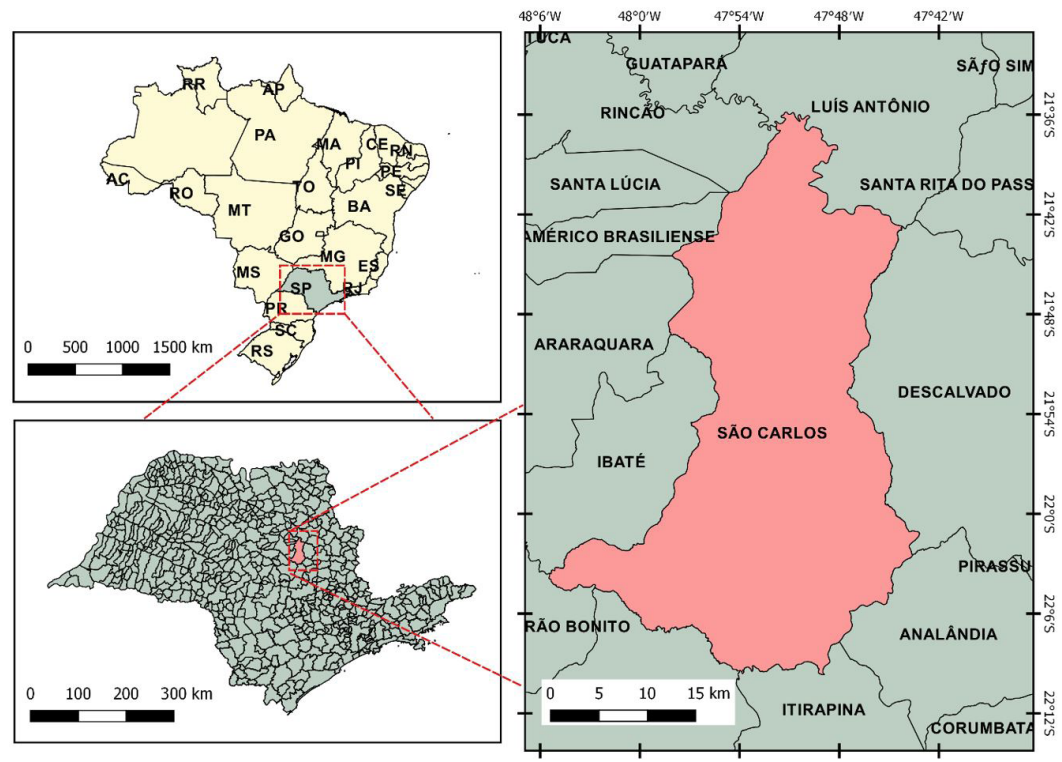

Figure 1. Map showing the location of São Carlos municipality, São Paulo (SP) state, Brazil.

Table 1. Crops planted area (ha) in São Carlos (SP) during the study period. The percentages indicate the relation between the crop planted area and the total area for temporary crops and the relation between the crop planted area and the municipality total area, respectively.

\begin{tabular}{|c|c|c|c|c|c|c|c|}
\hline C & 2004 & 2005 & 2006 & 2007 & 2008 & 2009 & 2010 \\
\hline \multirow{3}{*}{1} & 23867 & 24220 & 23867 & 23000 & 23000 & 38084 & 37943 \\
\hline & $83.7 \% / 20.99 \%$ & $85.4 \% / 21.30 \%$ & $85.5 \% / 20.99 \%$ & $87.2 \% / 20.23 \%$ & $87.0 \% / 20.23 \%$ & $94.0 \% / 33.5 \%$ & $98.1 \% / 33.37 \%$ \\
\hline & 3580 & 3080 & 3580 & 2900 & 3000 & 2000 & 300 \\
\hline 2 & $12.6 \% / 3.15 \%$ & $10.9 \% / 2.71 \%$ & $12.8 \% / 3.15 \%$ & $10.4 \% / 2.55 \%$ & $11.3 \% / 2.64 \%$ & $4.94 \% / 1.76 \%$ & $0.78 \% / 0.26 \%$ \\
\hline \multirow{2}{*}{3} & 1000 & 1000 & 400 & 400 & 400 & 400 & 400 \\
\hline & $3.51 \% / 0.88 \%$ & $3.52 \% / 0.88 \%$ & $1.43 \% / 0.35 \%$ & $1.43 \% / 0.35 \%$ & $1.51 \% / 0.35 \%$ & $0.99 \% / 0.35 \%$ & $1.03 \% / 0.35 \%$ \\
\hline \multirow{2}{*}{4} & 10 & 15 & 15 & 12 & 12 & 9 & 9 \\
\hline & $0.04 \% / 0.01 \%$ & $0.05 \% / 0.01 \%$ & $0.05 \% / 0.01 \%$ & $0.04 \% / 0.01 \%$ & $0.05 \% / 0.05 \%$ & $0.02 \% / 0.01 \%$ & $0.02 \% / 0.01 \%$ \\
\hline 5 & $\begin{array}{c}9 \\
0.03 \% / 0.01 \%\end{array}$ & $\stackrel{6}{6} 0.03 \% / 0.01 \%$ & $\begin{array}{c}9 \\
0.03 \%\end{array} / 0.01 \%$ & $\begin{array}{c}9 \\
0.03 \%\end{array}$ & $\begin{array}{c}9 \\
0.03 \%\end{array} / 0.01 \%$ & $\begin{array}{c}9 \\
0.02 \% / 0.01 \%\end{array}$ & $\begin{array}{c}9 \\
0.02 \% / 0.01 \%\end{array}$ \\
\hline 6 & $\begin{array}{c}25 \\
0.09 \% / 0.02 \%\end{array}$ & $\begin{array}{c}25 \\
0.09 \% / 0.02 \%\end{array}$ & $\begin{array}{c}25 \\
0.09 \% / 0.02 \%\end{array}$ & $\begin{array}{c}25 \\
0.09 \% / 0.02 \%\end{array}$ & $\begin{array}{c}25 \\
0.09 \% / 0.02 \%\end{array}$ & --- & --- \\
\hline 7 & $\begin{array}{c}30 \\
0.11 \% / 0.03 \%\end{array}$ & $\begin{array}{c}30 \\
0.07 \% / 0.02 \%\end{array}$ & $\begin{array}{c}20 \\
0.07 \% / 0.02 \%\end{array}$ & $\begin{array}{c}20 \\
0.07 \% / 0.02 \%\end{array}$ & --- & --- & -- \\
\hline 8 & --- & --- & --- & -- & --- & --- & --- \\
\hline $\mathbf{T}$ & $\begin{array}{c}28521 \\
100 \% / 25.09 \% \\
\end{array}$ & $\begin{array}{c}28376 \\
100 \% / 24.96 \% \\
\end{array}$ & $\begin{array}{c}27916 \\
83.7 \% / 24.55 \% \\
\end{array}$ & $\begin{array}{c}26366 \\
100 \% / 20.99 \% \\
\end{array}$ & $\begin{array}{c}26446 \\
100 \% / 23.26 \% \\
\end{array}$ & $\begin{array}{c}40502 \\
100 \% / 35.62 \%\end{array}$ & $\begin{array}{c}38661 \\
83.7 \% / 34.00 \% \\
\end{array}$ \\
\hline $\mathrm{C}$ & 2011 & 2012 & 2013 & 2014 & 2015 & 2016 & 2017 \\
\hline \multirow[b]{2}{*}{1} & 38084 & 32967 & 32967 & 32500 & 34500 & 35000 & 35000 \\
\hline & $\begin{array}{c}98.0 \% / 33.50 \% \\
350\end{array}$ & $\begin{array}{c}91.6 \% / 29.00 \% \\
2500\end{array}$ & $\begin{array}{c}91.25 \% / 29.00 \% \\
2700\end{array}$ & $\begin{array}{c}91.27 \% / 28.59 \% \\
1900\end{array}$ & $\begin{array}{c}86.32 \% / 30.34 \% \\
1700\end{array}$ & $\begin{array}{c}91.96 \% / 30.78 \% \\
1500\end{array}$ & $\begin{array}{c}91.32 \% / 30.78 \% \\
1800\end{array}$ \\
\hline 2 & $0.90 \% / 0.31 \%$ & $6.94 \% / 2.20 \%$ & $7.47 \% / 2.37 \%$ & $5.34 \% / 1.67 \%$ & $4.25 \% / 1.50 \%$ & $3.94 \% / 1.32 \%$ & $4.70 \% / 1.58 \%$ \\
\hline 3 & $\begin{array}{c}400 \\
1.03 \% / 0.35 \%\end{array}$ & $\begin{array}{c}500 \\
1.39 \% / 0.44 \%\end{array}$ & $\begin{array}{c}400 \\
1.11 \% / 0.35 \%\end{array}$ & $\begin{array}{c}700 \\
1.97 \% / 0.62 \%\end{array}$ & $\begin{array}{c}700 \\
1.75 \% / 0.62 \%\end{array}$ & $\begin{array}{c}1500 \\
3.94 \% / 1.32 \%\end{array}$ & $\begin{array}{c}1500 \\
3.91 \% / 1.32 \%\end{array}$ \\
\hline 4 & $\begin{array}{c}12 \\
0.03 \% / 0.01 \%\end{array}$ & $\begin{array}{c}12 \\
0.03 \% / 0.01 \%\end{array}$ & $\begin{array}{c}12 \\
0.03 \% / 0.01 \%\end{array}$ & $\begin{array}{c}10 \\
0.03 \% / 0.01 \%\end{array}$ & $\begin{array}{c}10 \\
0.03 \% / 0.01 \%\end{array}$ & $\begin{array}{c}12 \\
0.03 \% / 0.01 \%\end{array}$ & $\begin{array}{c}10 \\
0.03 \% / 0.01 \%\end{array}$ \\
\hline 5 & $\begin{array}{c}12 \\
0.03 \% / 0.01 \%\end{array}$ & $\begin{array}{c}10 \\
0.03 \% / 0.01 \%\end{array}$ & $\begin{array}{c}25 \\
0.07 \% / 0.02 \%\end{array}$ & $\begin{array}{c}30 \\
0.08 \% / 0.03 \%\end{array}$ & $\begin{array}{c}38 \\
0.10 \% / 0.03 \%\end{array}$ & $\begin{array}{c}30 \\
0.08 \% / 0.03 \%\end{array}$ & $\begin{array}{c}15 \\
0.04 \% / 0.01 \%\end{array}$ \\
\hline 6 & $\begin{array}{c}25 \\
0.06 \% / 0.02 \%\end{array}$ & $\begin{array}{c}20 \\
0.06 \% / 0.02 \%\end{array}$ & $\begin{array}{c}20 \\
0.06 \% / 0.02 \%\end{array}$ & $\begin{array}{c}20 \\
0.06 \% / 0.02 \%\end{array}$ & $\begin{array}{c}20 \\
0.05 \% / 0.02 \%\end{array}$ & $\begin{array}{c}20 \\
0.05 \% / 0.02 \%\end{array}$ & --- \\
\hline 7 & --- & --- & $\begin{array}{c}5 \\
0.01 \% / 0.004 \%\end{array}$ & --- & --- & --- & --- \\
\hline 8 & --- & --- & --- & $\begin{array}{c}450 \\
1.26 \% / 0.40 \%\end{array}$ & $\begin{array}{c}3000 \\
7.51 \% / 2.64 \%\end{array}$ & --- & --- \\
\hline$T$ & $\begin{array}{c}\mathbf{3 8 8 8 3} \\
100 \% / 34.20 \% \\
\end{array}$ & $\begin{array}{c}\mathbf{3 6 0 0 9} \\
100 \% / 31.67 \%\end{array}$ & $\begin{array}{c}\mathbf{3 6 1 2 9} \\
100 \% / 31.78 \%\end{array}$ & $\begin{array}{c}35610 \\
100 \% / 31.32 \%\end{array}$ & $\begin{array}{c}39968 \\
100 \% / 35.15 \%\end{array}$ & $\begin{array}{c}38062 \\
100 \% / 33.48 \%\end{array}$ & $\begin{array}{c}38325 \\
100 \% / 33.71 \%\end{array}$ \\
\hline
\end{tabular}

C = Crops; 1 = Sugarcane; 2 = Maize; 3 = Soybeans; 4 = Tomato; 5 = Cassava; 6 = Rice; 7 = Beans; 8 = Groundnut; $\mathrm{T}$ = total area of temporary crops. Source: Instituto Brasileiro de Geografia e Estatística (2018). 
Table 2. Planting and harvesting dates considered in the CROPWAT model.

\begin{tabular}{|c|c|c|c|c|}
\hline Crop & Planting order & Plant date & Harvest date & Stage (days) \\
\hline 1 & ---- & $01 / 09$ & $31 / 08$ & 365 \\
\hline 2 & $\begin{array}{l}\text { 1st planting } \\
\text { 2nd planting }\end{array}$ & $\begin{array}{l}01 / 09 \\
01 / 02\end{array}$ & $\begin{array}{l}03 / 01 \\
05 / 06\end{array}$ & $\begin{array}{l}125 \\
125\end{array}$ \\
\hline 3 & --- & $01 / 11$ & $24 / 01$ & 85 \\
\hline 4 & ---- & $01 / 02$ & $25 / 06$ & 145 \\
\hline 5 & ---- & 01/09 & $29 / 03$ & 210 \\
\hline 6 & ---- & $01 / 10$ & $28 / 01$ & 120 \\
\hline 7 & $\begin{array}{l}\text { 1st planting } \\
\text { 2nd planting } \\
\text { 3rd planting }\end{array}$ & $\begin{array}{l}01 / 09 \\
01 / 01 \\
01 / 05\end{array}$ & $\begin{array}{l}19 / 12 \\
20 / 04 \\
18 / 08\end{array}$ & $\begin{array}{l}110 \\
110 \\
110\end{array}$ \\
\hline 8 & $\begin{array}{l}\text { 1st planting } \\
\text { 2nd planting }\end{array}$ & $\begin{array}{l}01 / 09 \\
01 / 02\end{array}$ & $\begin{array}{l}08 / 01 \\
08 / 06\end{array}$ & $\begin{array}{l}130 \\
130\end{array}$ \\
\hline
\end{tabular}

1 = Sugarcane; 2 = Maize; 3 = Soybeans; 4 = Tomato; 5 = Cassava; 6 = Rice; 7 = Beans; 8 = Groundnut. Source: Companhia Nacional de Abastecimento (2019a) and Empresa Brasileira de Pesquisa Agropecuária (2019a).

where: $\mathrm{CWU}_{\text {blue }}$ : blue component in crop water use $\left(\mathrm{m}^{3} \mathrm{ha}^{-1}\right) ; \mathrm{CWU} \mathrm{green}_{\text {in }}$ : green component in crop water use $\left(\mathrm{m}^{3} \mathrm{ha}^{-1}\right)$; $\mathrm{Y}=$ crop yield $\left(\right.$ ton $\left.\mathrm{ha}^{-1}\right) ; \alpha=$ leaching-runoff fraction; $\mathrm{AR}=$ chemical application rate to the field $\left(\mathrm{kg} \mathrm{ha}^{-1}\right) ; \mathrm{c}_{\max }=$ maximum acceptable concentration for the pollutant considered $\left(\mathrm{kg} \mathrm{m}^{-3}\right)$; and $\mathrm{c}_{\text {nat }}=$ natural concentration for the pollutant considered $\left(\mathrm{kg} \mathrm{m}^{-3}\right)$. Here, the water footprint values are expressed in water volume per mass $\left(\mathrm{m}^{3}\right.$ ton $\left.^{-1}\right)$.

The crop water use $\left(\mathrm{CWU}_{\text {blue }}\right.$ and $\left.\mathrm{CWU} \mathrm{U}_{\text {green }}\right)$ was determined using the CROPWAT 8.0 model (Allen et al., 1998). The model analyzes the amount of rainwater incorporated by the crop (the green component of the water demand), as shown in Equation 4, and the irrigation demand (the blue component of the water demand), as shown in Equation 5.

$$
\begin{aligned}
& C W U_{\text {blue }}=10 * \sum_{d=l}^{l g p} E T_{\text {blue }} \\
& C W U_{\text {green }}=10 * \sum_{d=l}^{l g p} E T_{\text {green }}
\end{aligned}
$$

where: lgp: length of growing period (days); d: day of planting; $\mathrm{ET}_{\text {green }}$ : green water evapotranspiration $\left(\mathrm{mm} \mathrm{day}^{-1}\right)$; and $\mathrm{ET}_{\text {blue }}=$ blue water evapotranspiration $\left(\mathrm{mm} \mathrm{day}^{-1}\right)$.

These two parts together provide crop evapotranspiration. The calculation of these components considered the crops under optimal development conditions, using only climatic and crop data, once there is not a detailed information about irrigation schedule in a local scale.

\section{Data collection}

Climate data were collected at the Climatological Station of the Water Resources and Applied Ecology Center (CRHEA) from the University of São Paulo (USP), and consist of maximum and minimum temperature, humidity, wind speed, insolation, and rainfall.
The crop data used were: crop coefficient $\left(\mathrm{K}_{\mathrm{c}}\right)$; length of growth stage; and root depth. They were obtained from the global CROPWAT defaults (Allen et al., 1998). Cassava was an exception because we used data from the Food and Agriculture Organization (2019).

São Carlos temporary crop yield data (Y) were obtained from the Instituto Brasileiro de Geografia e Estatística (2018). The data are available between 2004 and 2017 for sugarcane, maize, soybean, tomato, cassava, rice, beans, and groundnut.

Table 2 indicates the planting and harvesting crops calendar adapted from the Brazilian Grain Plantation and Harvest Calendar (Companhia Nacional de Abastecimento, 2019a) and Brazilian Agricultural Research Corporation (Empresa Brasileira de Pesquisa Agropecuária, 2019a) proposals. These dates were included in the CROPWAT model. The climatic data incorporated in the CROPWAT model followed the planting and harvesting calendar, from September of the first year to August of the following year, to cover all cultures growth.

For the $\mathrm{WF}_{\text {gray }}$, the nitrogen application rate was obtained from Empresa Brasileira de Pesquisa Agropecuária (2019a, 2020a, 2020b, 2020c, 2020d, 2020e, 2020f, 2020g), which indicates the average values used in Brazilian territory. We used only one value for crop, during the study period (Table 3), because there is not a historical data available. The leaching-runoff fraction $(\alpha)$ was assumed to be 10\% (Chapagain et al., 2006). The maximum concentrations of pollutants $\left(\mathrm{c}_{\max }\right)$ were obtained from Resolution $n^{\circ} 357 / 2005$ of the National Council of the Environment (CONAMA) (Brasil, 2005). For nitrate, the maximum concentration allowed is $10 \mathrm{mg} \mathrm{L}^{-1}$. Natural concentrations $\left(\mathrm{c}_{\mathrm{nat}}\right)$ were assumed to be zero due to the lack of local data, following the suggestion of Hoekstra et al. (2011)., We used only nitrogen rates to calculate $\mathrm{WF}_{\text {gray }}$ according to several studies found in the literature, which also allowed us to compare our results with those found in these studies (Bulsink et al., 2010, Mekonnen \& Hoekstra, 2011; Liu et al., 2012). 


\section{Data analysis}

We calculated the water footprint of the crops for each year of the study period (2004 to 2017) and analyzed the years where the results showed more discrepancy. The main base for results comparison was the global WF results (Mekonnen \& Hoekstra, 2011) (Table 4). Although they were estimated with data from 1996 to 2005, their findings can be used as a reference, considering the lack of similar results with global data. We also checked other recent studies (from 2009 to 2019) that analyzed the same crops in different places of the world, for approximation and validation of the results.

We applied statistical tests to verify the water footprint behavior over the years. Groundnut results was excluded from this analysis, considering that this crop was planted only in two years and this was not enough to use the tests correctly.

Table 3. The application rate of nitrogen compounds, in $\mathrm{kg} \mathrm{ha}^{-1}$.

\begin{tabular}{cc}
\hline Crop & $\begin{array}{r}\text { Fertilizer application rate } \\
\text { considered }(\mathbf{k g} / \mathbf{h a})\end{array}$ \\
\hline 1. Sugarcane & 87.5 \\
2. Maize & 60 \\
3. Soybeans & 10 \\
4. Tomato & 92.5 \\
5. Cassava & 30 \\
6. Rice & 85 \\
7. Beans & 105 \\
8. Groundnut & 13
\end{tabular}

Source: Empresa Brasileira de Pesquisa Agropecuária (2019a, 2020a, 2020b, 2020c, 2020d, 2020e, 2020f, 2020g).
First, we tested data distributions for normality, using the Shapiro-Wilk test, with a $95 \%$ confidence interval $(\alpha=0.05)$. If the test confirms the null hypothesis, the sample analyzed comes from a normal population. Otherwise, the alternative hypothesis indicates that the sample does not follow a normal distribution.

When the normal distribution has been confirmed, we applied two additional parametric tests: t-Student and the one-way analysis of variance (ANOVA) with Tukey test. If data do not follow normal distribution, these two tests were not applied. The t-student compares the mean results found in this study with the global mean values, (Mekonnen \& Hoekstra, 2011), determining if the two data sets are significantly different from each other. If the test confirms the null hypothesis, there is no difference between the sample (our results) and population (global values) means. Otherwise, the alternative hypothesis indicates a significant difference between the sample and the population means. A 95\% confidence interval was also considered.

The ANOVA was applied to compare means of two different crops, considering the same WF component. The null hypothesis indicates that the samples are from populations with the same mean values. Additionally, the Tukey test was applied to perform multiple comparisons between different crops in the same WF component.

We also used Mann-Kendall, a non-parametric test (Kendall \& Stuart, 1967; Mann, 1945), to check a monotonic upward or downward trend of each water footprint component. The null hypothesis indicates that the data originate from a population of independent and identically distributed measurements, with no trend. The alternative hypothesis indicates that data follows a monotonic trend, upward or downward. This test was applied only for the five crops with data in the whole period study (sugarcane, maize, soybean, tomato and cassava).

Table 4. Water footprint values, in $\mathrm{m}^{3} \operatorname{ton}^{-1}$, calculated by Mekonnen \& Hoekstra (2011). Columns indicate global values (minimum, mean and maximum, with the country and province/state of occurrence), national (mean) and sub-national (SP state).

\begin{tabular}{|c|c|c|c|c|c|c|}
\hline \multirow{2}{*}{ Crop } & \multirow{2}{*}{$\begin{array}{c}\text { WF } \\
\text { component }\end{array}$} & \multicolumn{3}{|c|}{ Global values } & \multicolumn{2}{|c|}{ Brazil } \\
\hline & & Minimum & Mean & Maximum & Mean & SP State \\
\hline \multirow[t]{7}{*}{ 1. Sugarcane } & Green & 11 & 139 & 10749 & 122 & 115 \\
\hline & & Egypt - Al Minya & & American Samoa & & \\
\hline & Blue & 0 & 57 & 507 & 5 & 4 \\
\hline & & Indonesia - Papua & & Nigeria - Jigawa & & \\
\hline & Gray & 0 & 13 & 266 & 10 & 10 \\
\hline & & Zambia & & Afghanistan - Badghis & & \\
\hline & Total & 11 & 209 & 11522 & 137 & 128 \\
\hline \multirow[t]{7}{*}{ 2. Maize } & Green & 33 & 947 & 21289 & 1621 & 1510 \\
\hline & & Kuwait - Al'Asimah & & Botswana - Southern & & \\
\hline & Blue & 0 & 81 & 8593 & 1 & 0 \\
\hline & & Bangladesh - Chittagong & & Sudan - An Nil al Azraq & & \\
\hline & Gray & 0 & 194 & 5316 & 125 & 113 \\
\hline & & Central African Republic - Haut Mbombou & & Dominica & & \\
\hline & Total & 33 & 1222 & 35198 & 1746 & 1622 \\
\hline \multirow[t]{7}{*}{ 3. Soybeans } & Green & 208 & 2037 & 36975 & 2181 & 2114 \\
\hline & & Egypt - Al Buhayrah & & Tajikistan - Kulyab & & \\
\hline & Blue & 0 & 70 & 161176 & 1 & 1 \\
\hline & & Russian Federation & & Tajikistan - Khudzhand & & \\
\hline & Gray & 0 & 37 & 89528 & 15 & 14 \\
\hline & & Pakistan & & Tajikistan - Kulyab & & \\
\hline & Total & 208 & 2144 & 287680 & 2197 & 2129 \\
\hline
\end{tabular}

Source: Mekonnen \& Hoekstra (2011). 
Table 4. Continued...

\begin{tabular}{|c|c|c|c|c|c|c|}
\hline \multirow{2}{*}{ Crop } & \multirow{2}{*}{$\begin{array}{c}\text { WF } \\
\text { component }\end{array}$} & \multicolumn{3}{|c|}{ Global values } & \multicolumn{2}{|c|}{ Brazil } \\
\hline & & Minimum & Mean & Maximum & Mean & SP State \\
\hline \multirow[t]{7}{*}{ 4. Tomato } & Green & 0.1 & 108 & 3234 & 68 & 71 \\
\hline & & Brunei Darussalam & & Somalia - Banaadir & & \\
\hline & Blue & 0 & 63 & 1777 & 19 & 14 \\
\hline & & Zimbabwe - Midlands & & Somalia - Shabeellaha Dhexe & & \\
\hline & Gray & 0 & 43 & 474 & 7 & 7 \\
\hline & & Zambia & & Cuba - Ciudad de la Habana & & \\
\hline & Total & 0.1 & 214 & 5486 & 94 & 92 \\
\hline \multirow[t]{7}{*}{ 5. Cassava } & Green & 47 & 550 & 3685 & 433 & 476 \\
\hline & & Saint Lucia & & Cayman Islands - G. Cayman & & \\
\hline & Blue & 0 & 0 & 459 & 1 & 0 \\
\hline & & Brazil - Amazonas & & Niger - Agadez & & \\
\hline & Gray & 0 & 13 & 267 & 17 & 14 \\
\hline & & Tanzania - Kilmanjaro & & Guyana - M.-Berbice & & \\
\hline & Total & 47 & 564 & 4412 & 451 & 490 \\
\hline \multirow[t]{7}{*}{ 6. Rice } & Green & 49 & 1146 & 8822 & 1943 & 2222 \\
\hline & & Egypt - Al Qalyubiyah & & Brunei - Temburong & & \\
\hline & Blue & 0 & 341 & 7405 & 356 & 96 \\
\hline & & Ecuador - Mor. Santiago & & Iraq - Maysan & & \\
\hline & Gray & 0 & 187 & $2145^{\circ}$ & 104 & 107 \\
\hline & & Central African Republic - Haut Mbombou & & Kyrgyztan - Jalal-Abad & & \\
\hline & Total & 49 & 1673 & 18372 & 2403 & 2425 \\
\hline \multirow[t]{7}{*}{ 7. Beans } & Green & 234 & 3945 & 12362 & 2761 & 2039 \\
\hline & & Libya - Al Jufrah & & India - Daman and Diu & & \\
\hline & Blue & 0 & 125 & 4771 & 62 & 54 \\
\hline & & Bangladesh - Chittagong & & Cyprus - Kyrenia & & \\
\hline & Gray & 0 & 983 & 19259 & 440 & 225 \\
\hline & & Ethiopia & & United States - Nevada & & \\
\hline & Total & 234 & 5053 & 36392 & 3264 & 2318 \\
\hline \multirow[t]{7}{*}{ 8. Groundnut } & Green & 72 & 2469 & 14267 & 2777 & 2815 \\
\hline & & Israel - HaMerkaz & & Angola - Zaire & & \\
\hline & Blue & 0 & 150 & 8956 & 3 & 1 \\
\hline & & Myanmar - Chin State & & Sudan - Janub Darfur & & \\
\hline & Gray & 0 & 163 & 3931 & 12 & 12 \\
\hline & & Venezuela & & Namibia - Luderitz & & \\
\hline & Total & 72 & 2782 & 27154 & 2793 & 2828 \\
\hline
\end{tabular}

Source: Mekonnen \& Hoekstra (2011).

Finally, we calculated the linear correlation coefficient between WF components and the yields of each crop. This coefficient can vary between -1 (negative correlation) and +1 (positive correlation), which indicates that variables are inversely or directly proportional, respectively. Values close to 0 indicate no linear relationship. We searched to visualize and delineate how crop productivity could influence each WF component. We expect negative values for these coefficients, once the yields are inversely proportional to WF components, as can be seen in Equations 1, 2, and 3. The values variation can indicate how strong the relation of both variables are and how it can probably influence in each other.

\section{RESULTS AND DISCUSSIONS}

\section{Water footprint calculation by crop and comparison of the results}

Table 5 summarizes the water footprint results in terms of mean and standard deviation values, for each temporary crop analyzed in this study. These values can be compared with the main global results (Mekonnen \& Hoekstra, 2011), highlighted in Table 4 (minimum, mean and maximum global values / Brazilian mean and SP state values). We also consulted other studies for further discussion.

In summary, this study allowed us to estimate the temporary crops water footprint in a Brazilian municipality, using preferentially local data. Sugarcane, tomato, soybeans and maize showed WF values below or near the global and national averages, which can reveal a good adaptation to local conditions. On the other hand, rice, beans and groundnut presented high values of WF, what it can mean a non-adaptation, and its cultivation is not recommended in São Carlos, considering water use. We highlight that the blue WF was overestimated, when comparing to the other studies. This probably happened because CROPWAT assumes optimal growth conditions, without water restriction.

The results and comparisons for each crop are discussed separately, in the following topics.

\section{Sugarcane}

Figure 2 shows the results for sugarcane, the crop with the highest planted area (average of $31071 \mathrm{ha}$ ) and the highest yield (average of 83 ton ha ${ }^{-1}$ ) in São Carlos/SP. The sugarcane 
Reis et al.

Table 5. Mean and standard deviation of the water footprint components, in $\mathrm{m}^{3} \mathrm{ton}^{-1}$, for the analyzed crops in this study.

\begin{tabular}{|c|c|c|c|c|}
\hline Crop & $\mathbf{W F}_{\text {green }}$ & $\mathbf{W F}_{\text {blue }}$ & $\mathbf{W F}_{\text {gray }}$ & $\mathbf{W F}_{\text {total }}$ \\
\hline 1. Sugarcane & $109.8 \pm 7.6^{a}$ & $45.9 \pm 13.1^{a}$ & $10.5 \pm 0.3^{a}$ & $166.2 \pm 9.4^{a}$ \\
\hline 2. Maize & $1203.4 \pm 234.3$ & $395.5 \pm 178.4^{b}$ & $124.0 \pm 26.6$ & $1722.8 \pm 392.2^{\mathrm{b}}$ \\
\hline 3. Soybeans & $1127.1 \pm 274.3$ & $118.0 \pm 84.3^{\mathrm{ab}}$ & $38.9 \pm 8.7$ & $1284.1 \pm 317.4^{\mathrm{b}}$ \\
\hline 4. Tomato & $56.2 \pm 15.4^{a}$ & $23.0 \pm 16.0^{a}$ & $18.0 \pm 5.8^{a}$ & $97.2 \pm 32.2^{a}$ \\
\hline 5. Cassava & $317.5 \pm 35.9^{a}$ & $19.5 \pm 18.4^{a}$ & $18.6 \pm 2.2^{a}$ & $355.7 \pm 41.3^{\mathrm{a}}$ \\
\hline 6. Rice & $2546.7 \pm 312.5$ & $2217.9 \pm 538.2^{\mathrm{c}}$ & $447.9 \pm 54.3$ & $5212.4 \pm 740.9$ \\
\hline 7. Beans & $5524.3 \pm 1018.7$ & $2220.0 \pm 676.1^{c}$ & $840.0 \pm 78.3$ & $8584.4 \pm 692.4$ \\
\hline 8. Groundnut & $2911.9 \pm 515.2$ & $894.5 \pm 493.4$ & $59.4 \pm 10.5$ & $3865.8 \pm 1019.1$ \\
\hline
\end{tabular}

$\mathrm{WF}_{\text {green }}$ : green water footprint; $\mathrm{WF}_{\text {blue }}$ : blue water footprint; $\mathrm{WF}_{\text {grax }}$ : gray water footprint. Identical lower-case letters indicate no significant difference between means in the same column by the Tukey means comparison test $(\mathrm{P}>0.05)$.

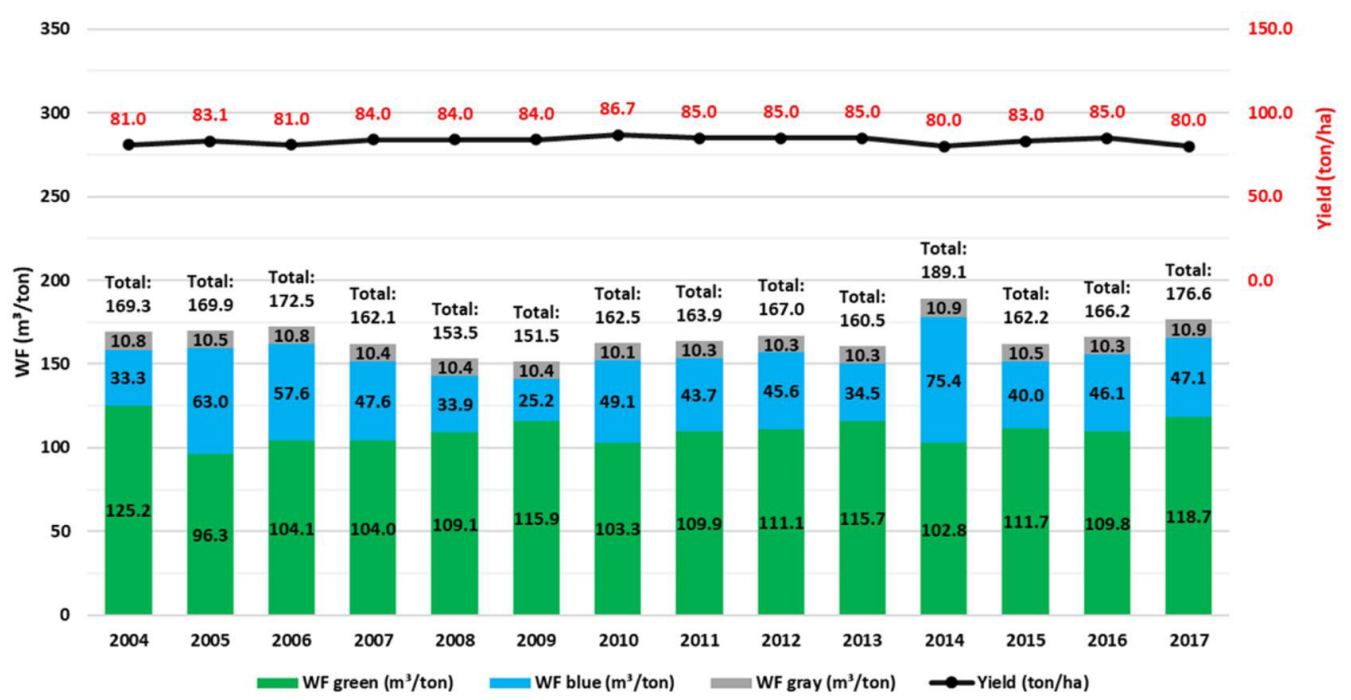

Figure 2. Sugarcane water footprint, in São Carlos/SP, between 2004 and 2017. The green part of the graph represents the green water footprint $\left(\mathrm{WF}_{\text {green }}\right)$, the blue part represents the blue water footprint $\left(\mathrm{WF}_{\text {blue }}\right)$ and the gray part represents the gray water footprint $\left(\mathrm{WF}_{\text {grax }}\right)$. The sum of the three plots is the total water footprint $\left(\mathrm{WF}_{\text {total }}\right)$. The graph also shows the crop yield over the years.

yield variation is minimum, varying from 80 to 86.7 ton ha ${ }^{-1}$, and cannot be indicated as a modifying factor of the water footprint. The significant increase in sugarcane production from 2009, due to the growth in the planted area (see Table 1), did not affect productivity.

Comparing the results with the global results (Mekonnen \& Hoekstra, 2011), the total values of water footprint (average of $166.2 \mathrm{~m}^{3}$ ton $\left.^{-1}\right)$ are lower than the world average $\left(209 \mathrm{~m}^{3}\right.$ ton $\left.^{-1}\right)$ for all years. Both results are near to the world minimum WF $\left(11 \mathrm{~m}^{3}\right.$ ton $\left.^{-1}\right)$ and far from the maximum WF $\left(11522 \mathrm{~m}^{3}\right.$ ton $\left.^{-1}\right)$ for sugarcane, according to Table 4 (Mekonnen \& Hoekstra, 2011). Analyzing the plots separately, the results are also lower than the global mean values. Only the blue water footprint exceeds the global average $\left(57 \mathrm{~m}^{3}\right.$ ton $\left.^{-1}\right)$ in $2005\left(63 \mathrm{~m}^{3}\right.$ ton $\left.^{-1}\right)$ and $2006\left(57.6 \mathrm{~m}^{3}\right.$ ton $\left.^{-1}\right)$. There was a small variation of the gray component compared to the global average. Our results are also close to the Brazilian values identified in the global study (Mekonnen \& Hoekstra, 2011), for green and gray components. The exception is the blue WF, that was nine time bigger. As we considered an optimal development condition for crops growing, with no restriction of irrigation, we can expect that this component achieve bigger values.

Scarpare et al. (2016) calculated sugarcane water footprint in the Tietê/Jacaré watershed, where part of São Carlos' territory is inserted. They found 145, 38 and $18 \mathrm{~m}^{3}$ ton $^{-1}$ as the average results for green, blue and gray components, respectively, considering sugarcane as the semi-permanent culture, which was harvested for five consecutive years, with different yields, different irrigation, and fertilization scenarios, during this cultivation period. With different assumptions, their results are close to the values obtained in this study, with negligible deviations, even for the blue component, which was the critical value, when comparing with the Brazilian results calculated in the global study (Mekonnen \& Hoekstra, 2011). This fact highlights the importance of local studies, with local data, to analyze the water use in agriculture, from WF concept. Also, both results indicate that sugarcane has a good adaptation to the regional climate and how this crop presents a low water footprint, especially in São Paulo state, where high productivity is achieved.

Anache et al. (2019) estimated sugarcane evapotranspiration at a study site in Itirapina/SP, a municipality near São Carlos/SP, with similar climate conditions. They found values for evapotranspiration of $801 \pm 212 \mathrm{~mm}_{\text {year }}{ }^{-1}$, considering water balance components, monitored over 5 years (2012 to 2016). Evapotranspiration is an important element for green and blue WF determination, and therefore their results are important to validate our calculations. For this study, sugarcane annual evapotranspiration modeled by CROPWAT was, on average, $1296 \pm 53 \mathrm{~mm}$ year $^{-1}$ This difference 
can be explained by the years considered in each study. Anache et al. (2019) used data from 2012 and 2016, when occurred a historical dry in the state of São Paulo (2014 and 2015), reducing water availability for crops, and consequently, evapotranspiration rates also reduced. Our study, on the other hand, considers a longer period (2004-2017), so this drought was compensated by years of high rainfall rates (2004, 2009 and 2011), which raised the average evapotranspiration rate. Another cause is the use of different values of $\mathrm{K}_{\mathrm{c}}$ applied in both studies. This comparison highlights how rainfall is important to agriculture and how it can affect the evapotranspiration, and consequently, green and blue WF values.

\section{Maize}

Figure 3 shows the results for maize, the second most planted crop in São Carlos/SP (2206 ha). The 2009 water footprint results show a great discrepancy with the other years. This may be because in 2009 the harvested area was lower than the planted area, causing a production loss by an external factor, for example, climate anomaly or disease. However, crop yields were still good, contributing to the water footprint reduction that year. On the other hand, there may have been a data collection problem, leading to yield values higher than those found in other years. The crop yield increase in 2009 was also observed in soybean and tomato crops.

The total water footprint values (average of $1722.8 \mathrm{~m}^{3}$ ton $^{-1}$ ) were higher than the global averages (Mekonnen \& Hoekstra, 2011), $1222 \mathrm{~m}^{3}$ ton $^{-1}$, in most years. Both results are closest to the minimum total WF $\left(33 \mathrm{~m}^{3}\right.$ ton $\left.^{-1}\right)$ than the maximum total WF $\left(35198 \mathrm{~m}^{3}\right.$ ton $\left.^{-1}\right)$ in the world. Observing the plots separately, the greatest differences appear in the blue water footprint, indicating a high irrigation demand or an overestimation in this component, caused again by modeling assumptions. Another possible explanation is the planting and harvesting calendar used, which considered two crops, with one of them in the dry season, requiring more irrigation water. That deviation also occurs when comparing our result for blue WF to the national and state averages, found in the global study, which can reinforce these two hypotheses. Considering the green component, consecutive plantings can lead to high values of a green water footprint because precipitation water is incorporated into the crop during the year. The maize gray water footprint (average of $124.0 \mathrm{~m}^{3}$ ton $^{-1}$ ) was lower than the global average $\left(194 \mathrm{~m}^{3}\right.$ ton $\left.^{-1}\right)$ in all years.

Gerbens-Leenes \& Hoekstra (2012) calculated the water footprint for maize in the main producing countries, which includes Brazil, considering data from 1996 to 2005. They confirmed that Brazilian maize has total water footprint values (approx. $1800 \mathrm{~m}^{3}$ ton $\left.{ }^{1}\right)$ higher than the global means, as seen in São Carlos. However, these authors showed that the blue component in Brazil is one of the lowest among the other evaluated countries. This result does not correspond with the values obtained in this study, where blue WF showed a high discrepancy with global means. These authors considered actual irrigation in WF calculation rather than irrigation requirement, which explains this difference. However, this approach is valuable when irrigation information is available, in a more detailed way, which was not the case during our study.

\section{Soybean}

The soybean total water footprint values $\left(1284.1 \mathrm{~m}^{3}\right.$ ton $\left.^{-1}\right)$ were lower than the global average $\left(2144 \mathrm{~m}^{3}\right.$ ton $\left.^{-1}\right)$, as shown in Figure 4. Again, we observe that the São Carlos total WF values are below the global average and closer to the minimum result at global scale $\left(208 \mathrm{~m}^{3}\right.$ ton $\left.^{-1}\right)$ and far from the maximum $\left(287660 \mathrm{~m}^{3}\right.$ ton $\left.^{-1}\right)$ The green component was $45 \%$ smaller than the world average $\left(2037 \mathrm{~m}^{3}\right.$ ton $\left.^{-1}\right)$, suggesting favorable water availability conditions for the crop. The planting and harvesting calendar used for soybean was only one crop per year. Thus, the positive variations of the green component are not the result of new planting in sequence. The blue water footprint results varied greatly ( 0 to $265.7 \mathrm{~m}^{3}$ ton $\left.^{-1}\right)$ during the years, but the average value $\left(118.0 \mathrm{~m}^{3}\right.$ ton $\left.^{-1}\right)$ is not so far to the global average $\left(70 \mathrm{~m}^{3}\right.$ ton $\left.^{-1}\right)$, which deviation is again linked to the no water restriction of CROPWAT modeling. The mean

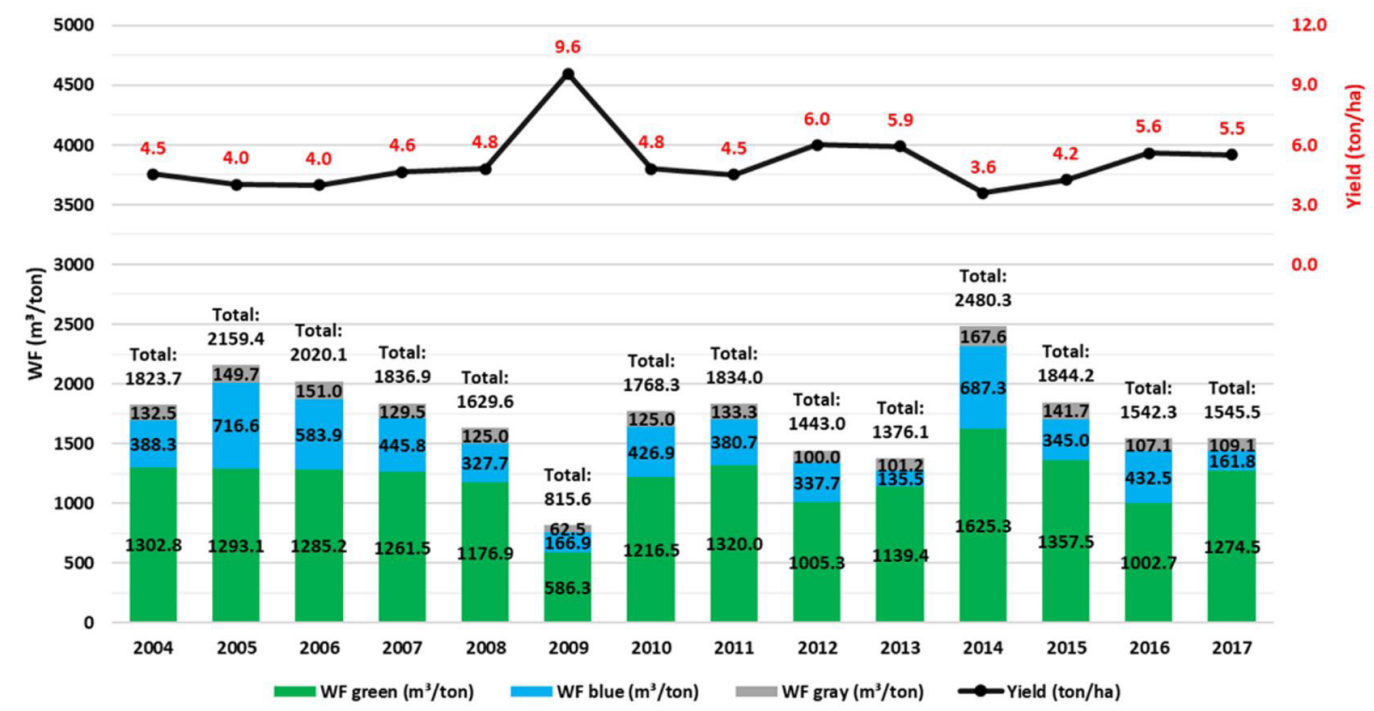

Figure 3. Maize water footprint, in São Carlos/SP, between 2004 and 2017. The green part of the graph represents the green water footprint $\left(\mathrm{WF}_{\text {green }}\right)$, the blue part represents the blue water footprint $\left(\mathrm{WF}_{\text {blue }}\right)$ and the gray part represents the gray water footprint $\left(\mathrm{WF}_{\text {grax }}\right)$. The sum of the three plots is the total water footprint $\left(\mathrm{WF}_{\text {total }}\right)$. The graph also shows the crop yield over the years. 
gray WF $\left(38.9 \mathrm{~m}^{3}\right.$ ton $\left.^{-1}\right)$ is almost the same of the global mean value $\left(37 \mathrm{~m}^{3}\right.$ ton $\left.^{-1}\right)$. Considering the Brazilian values, obtained in the global study, we observe that our green component is almost a half smaller, while blue and gray components presents elevated deviations. The explanation for blue component is the same of the other crops. In terms of gray component, soybean demands little or no use of nitrogen compounds for fertilization when planted in the Cerrado biome (Mendes et al. 2007). However, its common to visualize this application in small properties, what justifies the consideration of little application rate (Empresa Brasileira de Pesquisa Agropecuária, 2020c).

Zhuo et al. (2014) calculated soybeans WF in a region near Beijing, China. Their average results are similar to those of São Carlos for the green component $\left(1195.6 \mathrm{~m}^{3}\right.$ ton $^{-1}$ versus $1127.1 \mathrm{~m}^{3}$ ton $\left.^{-1}\right)$. For gray component, we observe a great deviation $\left(266.4 \mathrm{~m}^{3}\right.$ ton $^{-1}$ in China versus $38.9 \mathrm{~m}^{3}$ ton- ${ }^{-1}$ in São Carlos, $37 \mathrm{~m}^{3}$ ton $^{-1}$ in the global average and $15 \mathrm{~m}^{3}$ ton $^{-1}$ in Brazilian average). The authors considered an application fertilizer rate of $47.6 \mathrm{~kg} \mathrm{ha}^{-1}$, almost five times of that was considered in this study. Another significant factor is the low soybean yields in China (approx. 1.7 ton ha ${ }^{-1}$ ), while in São Carlos it is higher than 2.1 ton ha ${ }^{-1}$. Regarding blue WF, soybeans produced in São Carlos demand half of the irrigation required in China (118.0 $\mathrm{m}^{3}$ ton $^{-1}$ versus $354.3 \mathrm{~m}^{3}$ ton $\left.^{-1}\right)$.

\section{Tomato}

Figure 5 shows the tomato water footprint results. The $\mathrm{WF}_{\text {blue }}$ average value was $23 \mathrm{~m}^{3}$ ton $^{-1}, 56.2 \mathrm{~m}^{3}$ ton $^{-1}$ for $\mathrm{WF}_{\text {green }}$ and $18.0 \mathrm{~m}^{3}$ ton $^{-1}$ for $\mathrm{WF}_{\text {gray }}$. None of the three plots exceeded the global mean values and also remains close to the lowest values of each component in the world (Table 4, Mekonnen \& Hoekstra, 2011). Considering Brazilian results in the global study, São Carlos tomatoes presented more consumption of blue and

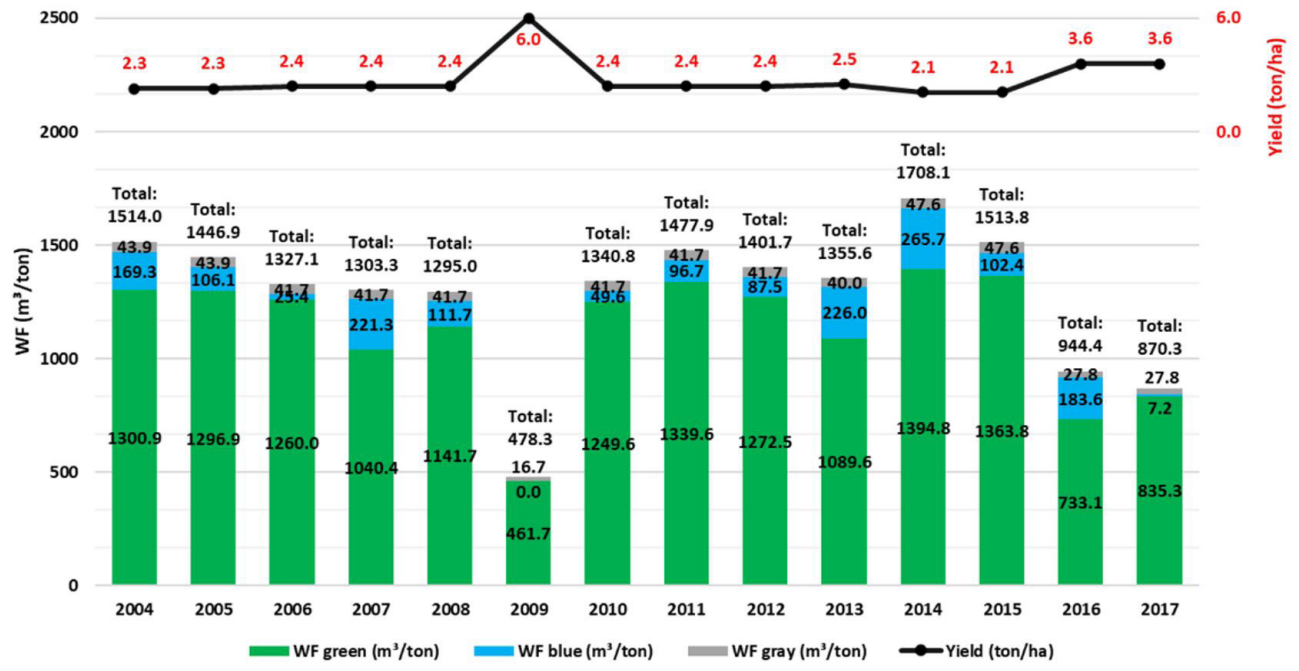

Figure 4. Soybean water footprint, in São Carlos/SP, between 2004 and 2017. The green part of the graph represents the green water footprint $\left(\mathrm{WF}_{\text {green }}\right)$, the blue part represents the blue water footprint $\left(\mathrm{WF}_{\text {blue }}\right)$ and the gray part represents the gray water footprint $(\mathrm{WF}$ gray $)$. The sum of the three plots is the total water footprint $\left(\mathrm{WF}_{\text {total }}\right)$. The graph also shows the crop yield over the years.

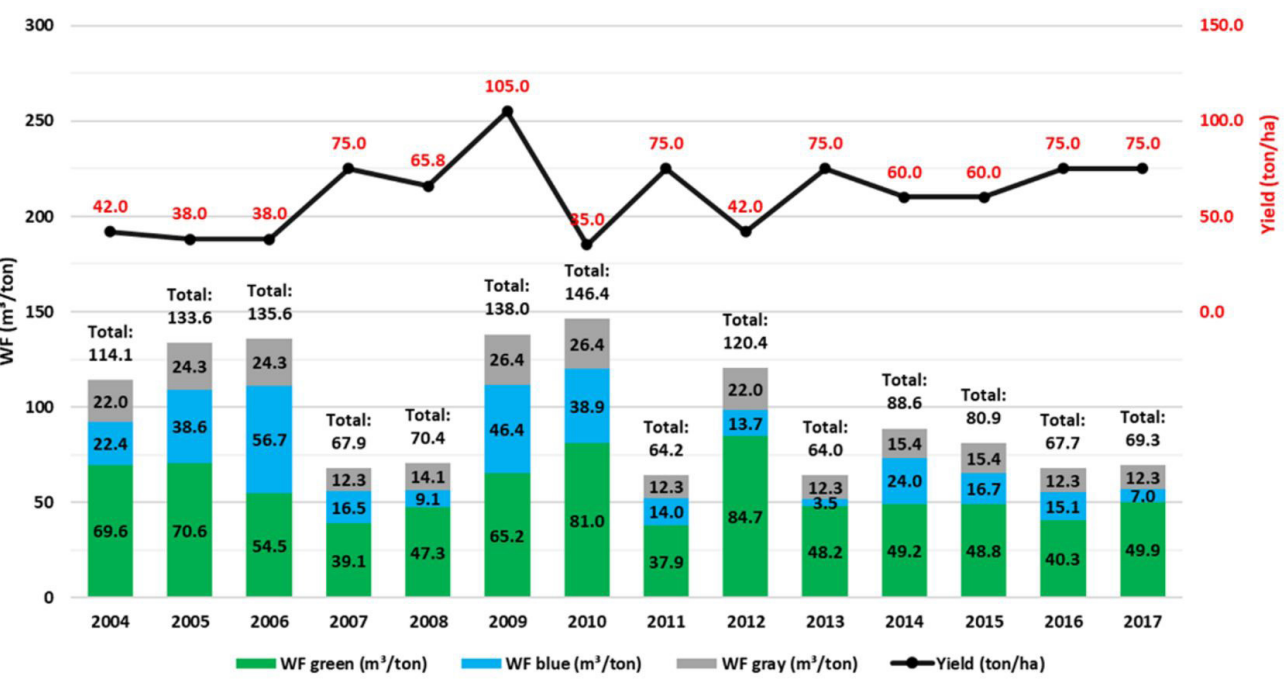

Figure 5. Tomato water footprint, in São Carlos/SP, between 2004 and 2017. The green part of the graph represents the green water footprint $\left(\mathrm{WF}_{\text {green }}\right)$, the blue part represents the blue water footprint $\left(\mathrm{WF}_{\text {blu }}\right)$ and the gray part represents the gray water footprint $\left(\mathrm{WF}_{\text {gray }}\right)$. The sum of the three plots is the total water footprint $\left(\mathrm{WF}_{\text {total }}\right)$. The graph also shows the crop yield over the years. 
grey water, while the green component was below the national and state average.

According to the historical record we generated, it could be observed that 2007 and 2016 show the lowest water footprint total values, 67.9 and $67.7 \mathrm{~m}^{3}$ ton $^{-1}$ respectively, due to the high crop yields. It should be mentioned that 2009 was not considered in this evaluation, because of the possible data failure, as already commented. From 2013 to 2014, yield values decreased from 75 to 60 ton $\mathrm{ha}^{-1}$ and green water footprint values remained remarkably close (48.2 and $49.2 \mathrm{~m}^{3}$ ton $\left.^{-1}\right)$. In these same years, the blue component varied considerably, from 3.5 to $24 \mathrm{~m}^{3}$ ton $^{-1}$, possibly compensating the crop water demand, not supplied by the green component, once low rainfall was observed in 2014.

Chapagain \& Orr (2009) determined WF for the Spanish production of tomatoes, considering both open (in fields) and covered (greenhouses) systems. They reached, as a national average result, 13.6, 60.5 and $7.2 \mathrm{~m}^{3}$ ton $^{-1}$ for the green, blue and gray components, respectively. Aldaya \& Hoekstra (2010) calculated WF for industrial tomatoes, for pasta and pizza consumption in Italy. They obtained, also at a national level, average results of 35,60 and $19 \mathrm{~m}^{3}$ ton $^{-1}$ for the green, blue and gray components, respectively. We note a difference in blue WF, compared to São Carlos tomatoes. Italian tomatoes consume more water from irrigation than the Brazilian case, where the green component is dominant, indicating a good adaptation to the region. For gray WF, we can see a considerable variation, due to different fertilizer inputs, indicating intensive use of chemicals in this crop (Rinaldi et al., 2006).

\section{Cassava}

Figure 6 presents the cassava water footprint results. The total average value was $355.7 \mathrm{~m}^{3}$ ton $^{-1}$, lower than the world average, $564 \mathrm{~m}^{3}$ ton $^{-1}$ and well bellow of the maximum value observed around the globe $\left(4412 \mathrm{~m}^{3}\right.$ ton $\left.^{-1}\right)$ (Mekonnen \& Hoekstra, 2011). Considering national and regional results in the global study, we observe similarity with our results in green and grey components, while blue WF remains overestimated.

The growth of crop yield from 15 ton ha $^{-1}$ in 2012 to 20.4 ton ha $^{-1}$ in 2013 caused a decrease in $\mathrm{WF}_{\text {green }}$ from 348.4 to $262.4 \mathrm{~m}^{3}$ ton $^{-1}$. The green component has the lowest variation compared with the world average $\left(550 \mathrm{~m}^{3}\right.$ ton $\left.^{-1}\right)$. For the blue water footprint, the world average and the Brazilian average value are minimum, below $1 \mathrm{~m}^{3}$ ton $^{-1}$. Here, the values remained between $0 \mathrm{~m}^{3}$ ton $^{-1}$ and $60 \mathrm{~m}^{3}$ ton $^{-1}$, which indicates more dependency of irrigation and a lack of enough rainfall for this culture, when compared to other regions (like Amazon in Brazil, where the blue component is zero). The gray water footprint values (average of $18.0 \mathrm{~m}^{3}$ ton $^{-1}$ ) were similar to the global mean value $\left(13 \mathrm{~m}^{3}\right.$ ton $\left.^{-1}\right)$, Brazilian mean value $\left(17 \mathrm{~m}^{3}\right.$ ton $\left.^{-1}\right)$ and SP state mean value $\left(14 \mathrm{~m}^{3}\right.$ ton $\left.^{-1}\right)$.

Kongboon \& Sampattagul (2012) analyzed this crop production in Northern Thailand. They found average values of 192,232 and $85 \mathrm{~m}^{3}$ ton $^{-1}$ for the green, blue and gray components, respectively. The Thai cassava WF is very close to the global average (Mekonnen \& Hoekstra, 2011), regarding the total value, but with larger differences in their components. The blue component is very high and exceeds the green water footprint. In our results, there is a lower irrigation demand. For the gray component, Thai values are bigger than the results found in our study.

\section{Rice}

Figure 7 shows the water footprint results for rice. There is intensive use of water resources in rice cultivation, because this crop is heavily dependent on irrigation, with $85 \%$ of the world's production being cultivated in flooded lands (Bouman et al., 2007). In 2007, 2008 and 2014, the blue water footprint (2518.5, 2197.5 and $3534.8 \mathrm{~m}^{3}$ ton $^{-1}$ respectively), exceeded the green water footprint $\left(2186,2137.5\right.$ and $2850.3 \mathrm{~m}^{3}$ ton $^{-1}$, respectively). In 2014, where the blue water footprint superiority was more evident, the lowest rainfall rate in the area was observed.

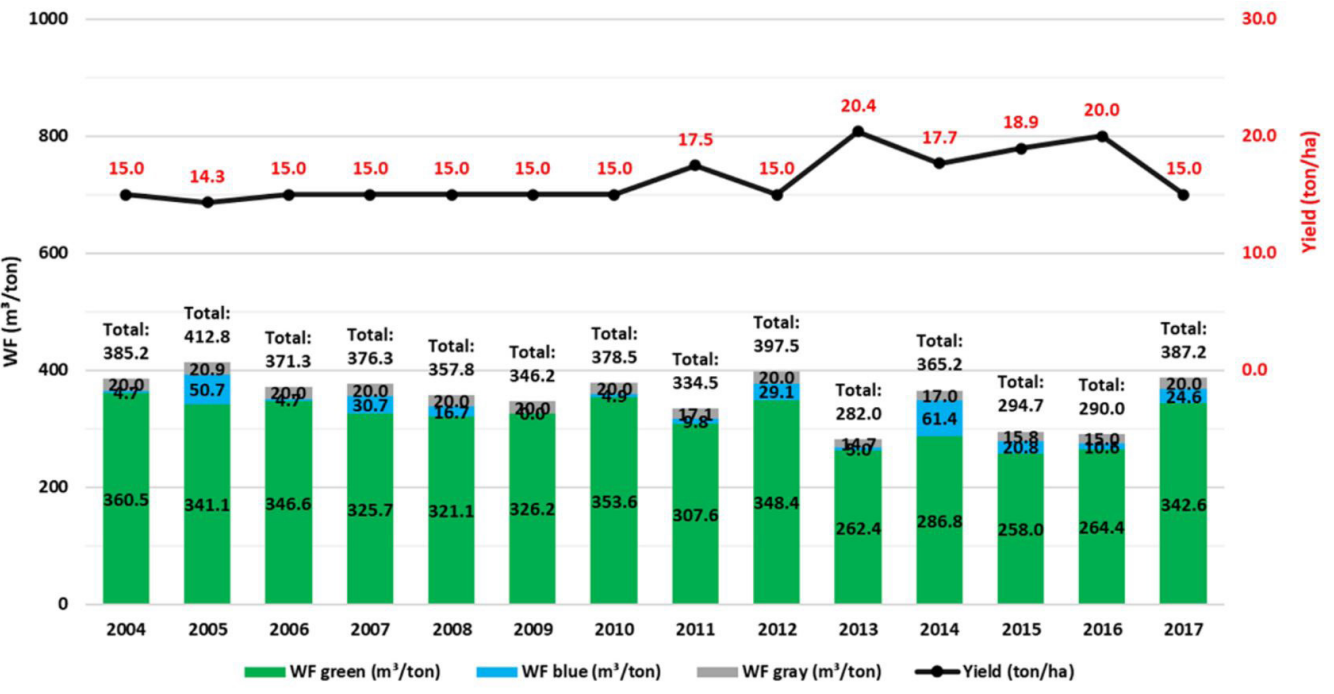

Figure 6. Cassava water footprint, in São Carlos/SP, between 2004 and 2017. The green part of the graph represents the green water footprint $\left(\mathrm{WF}_{\text {green }}\right)$, the blue part represents the blue water footprint $\left(\mathrm{WF}_{\text {blue }}\right)$ and the gray part represents the gray water footprint $\left(\mathrm{WF}_{\text {grax }}\right)$. The sum of the three plots is the total water footprint $\left(\mathrm{WF}_{\text {total }}\right)$. The graph also shows the crop yield over the years. 
The rice crop presented a low yield in the study area, 2 ton ha ${ }^{-1}$, close to the national average in the 1980s and 1990s (Empresa Brasileira de Pesquisa Agropecuária, 2019b). Currently, the national average yield approaches 5 to 6 ton ha ${ }^{-1}$ (Empresa Brasileira de Pesquisa Agropecuária, 2019b). This low productivity can indicate a delay in the use of new methods and technologies in this crop growing, leading to high water footprint values in São Carlos (SP). The green (average of $2546.7 \mathrm{~m}^{3}$ ton $^{-1}$ ) and gray (average of $447.9 \mathrm{~m}^{3}$ ton $^{-1}$ ) plots were 2 times greater than the global mean values (Mekonnen \& Hoekstra, 2011), $1146 \mathrm{~m}^{3}$ ton $^{-1}$ for WF and $187 \mathrm{~m}^{3}$ ton $^{-1}$ for $\mathrm{WF}_{\text {gray }}$. Even with high water consumption in the national and regional context, the rice WF values of São Carlos are well below the maximum results observed in the globe $\left(8822,7405,2145\right.$ and 18372 for $\mathrm{WF}_{\text {green, }} \mathrm{WF}_{\text {blue }}, \mathrm{WF}_{\text {gray }}$ and $\left.\mathrm{WF} \mathrm{F}_{\text {total }}\right)$ Considering Brazilian context, Mekonnen \& Hoekstra (2011) found 1943, 356 and $104 \mathrm{~m}^{3}$ ton $^{-1}$ as averages for $\mathrm{WF}_{\text {green, }}$ $\mathrm{WF}_{\text {blue }}$ and $\mathrm{WF}_{\text {gray }}$. Chapagain \& Hoekstra (2011) conducted a study of the water footprint in the 13 major rice-producing countries, including Brazil. They found 791, 670 and $61 \mathrm{~m}^{3}$ ton $^{-1}$ as average values for green, blue, and gray water footprints, respectively, in Brazilian plantations. The green and blue components are close to each other, as observed in our study, indicating high crop water demand. According to these results, we can conclude that rice cultivation in São Carlos uses a high amount of water, and is not the most appropriate crop for the region, concerning WF evaluation.

\section{Beans}

Figure 8 presents the results for the water footprint for beans. Beans presented an average of $8360.1 \mathrm{~m}^{3}$ ton $^{-1}$ for the total water footprint, higher than the global mean value, $5053 \mathrm{~m}^{3}$ ton $^{-1}$, but still below the greatest total values in the globe,

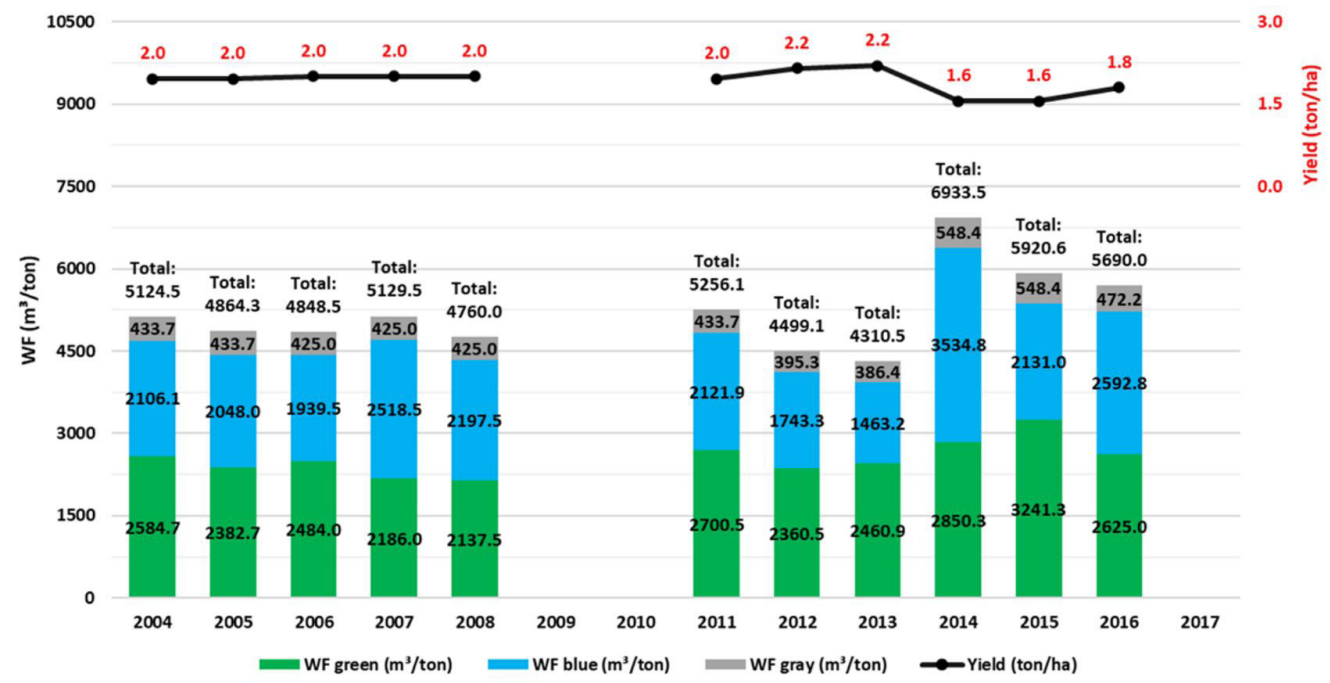

Figure 7. Rice water footprint, in São Carlos/SP, between 2004 and 2017. The green part of the graph represents the green water footprint $\left(\mathrm{WF}_{\text {green }}\right)$, the blue part represents the blue water footprint $\left(\mathrm{WF}_{\text {blue }}\right)$ and the gray part represents the gray water footprint $\left(\mathrm{WF}_{\text {gray }}\right)$. The sum of the three plots is the total water footprint $\left(\mathrm{WF}_{\text {total }}\right)$. The graph also shows the crop yield over the years.

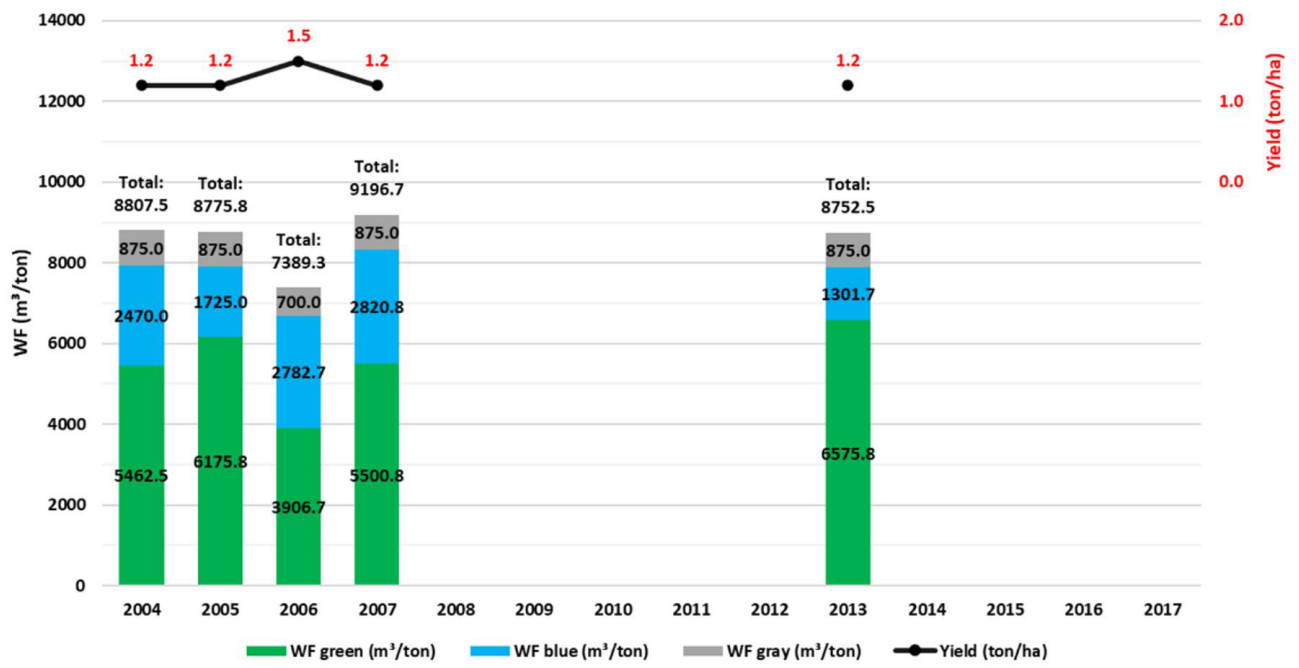

Figure 8. Bean water footprint in São Carlos/SP, between 2004 and 2017. The green part of the graph represents the green water footprint $\left(\mathrm{WF}_{\text {green }}\right)$, the blue part represents the blue water footprint $\left(\mathrm{WF}_{\text {blue }}\right)$ and the gray part represents the gray water footprint $\left(\mathrm{WF}_{\text {grax }}\right)$. The sum of the three plots is the total water footprint $\left(\mathrm{WF}_{\text {total }}\right)$. The graph also shows the crop yield over the years. 
$36392 \mathrm{~m}^{3}$ ton $^{-1}$ (Mekonnen \& Hoekstra, 2011). This crop can be planted and harvested three times in sequence, according to the calendar proposed by Companhia Nacional de Abastecimento (2019a). This fact raises the blue and green water footprint components, because of the water demand during the rainy and dry seasons. The crop yields in São Carlos did not vary significantly, and are close to the national average, according to Companhia Nacional de Abastecimento (2019b), indicating good management and crop adaptation to the local conditions. The most discrepant plot is the blue water footprint, with values above $2000 \mathrm{~m}^{3}$ ton $^{-1}$, while the world average is only $125 \mathrm{~m}^{3}$ ton $^{-1}$ and the Brazilian average is approximately $62 \mathrm{~m}^{3}$ ton $^{-1}$. The green component values present a small difference. The gray water footprint values, an average of $840 \mathrm{~m}^{3}$ ton $^{-1}$, were lower than the global mean $\left(983 \mathrm{~m}^{3}\right.$ ton $\left.^{-1}\right)$ in all years.

Lopez \& Bautista-Capetillo (2015) determined WF values for beans planted in Mexico. They simulated scenarios with different planting dates and irrigation conditions. Considering an irrigated crop, they obtained values between 2000 and $3500 \mathrm{~m}^{3}$ ton $^{-1}$ for the sum of green and blue components, varying according to the region where beans are cultivated. Considering global averages as a basis of comparison, Lopez and Bautista-Capetillo (2015) found a similarity in the green WF and a great variation in blue WF, once this component for Mexican beans was 14 times higher than the global averages. The same facts were detected in our study, for these two WF components.

\section{Groundnut}

Groundnut water footprint results are shown in Figure 9. It was difficult to find effective conclusions due to the small planting period (2014 and 2015) and the crop productivity variation. This crop is commonly harvested in rotation with other crops, specially sugarcane, with an important role in soil nitrogen fixation (Santos et al., 2009). Despite this, groundnut cultivation was estimated considering two harvests, considering both situations proposed by Companhia Nacional de Abastecimento (2019a). The crop yield values of São Carlos (1.9 ton ha ${ }^{-1}$ for 2014 and 2.5 ton ha ${ }^{-1}$ for 2015) are lower than the national average, which is approximately 3.8 ton $\mathrm{ha}^{-1}$ (Companhia Nacional de Abastecimento, 2019b). These two aspects are the main reasons for high water footprint levels. The total water footprint (average of $4147.2 \mathrm{~m}^{3}$ ton $^{-1}$ ) was higher than the global mean value, $2728 \mathrm{~m}^{3}$ ton $^{-1}$, and also higher than the national $\left(2793 \mathrm{~m}^{3}\right.$ ton $\left.^{-1}\right)$ and subnational $\left(2828 \mathrm{~m}^{3}\right.$ ton $\left.^{-1}\right)$ results, informed in the global study (Mekonnen \& Hoekstra, 2011). Even with high values, São Carlos results are far from the maximum values found in the globe $\left(27154 \mathrm{~m}^{3}\right.$ ton $\left.^{-1}\right)$

Bulsink et al. (2010) calculated WF components for primary crops in Indonesia, using data from 2000 to 2004. These authors found, for groundnut, average values of 2962, 162 and $0 \mathrm{~m}^{3}$ ton $^{-1}$ for the green, blue and gray components, respectively. Green WF was very close to the values calculated in our study, probably because of the climate similarity of both regions. However, blue and gray components presented larger discrepancies, possibly caused by the assumptions of two harvests in the same year and thelow yields observed in São Carlos.

\section{Statistical tests}

The results of the Mann-Kendall, Shapiro-Wilk and t-student tests are presented in Table 6. Each row shows a water footprint component (green, blue, gray and total), which are grouped by crop. The results are divided by color: white cells indicate null hypothesis confirmed by the test, and gray cells indicate rejection. In each cell, the correspondent p-value result is also shown.

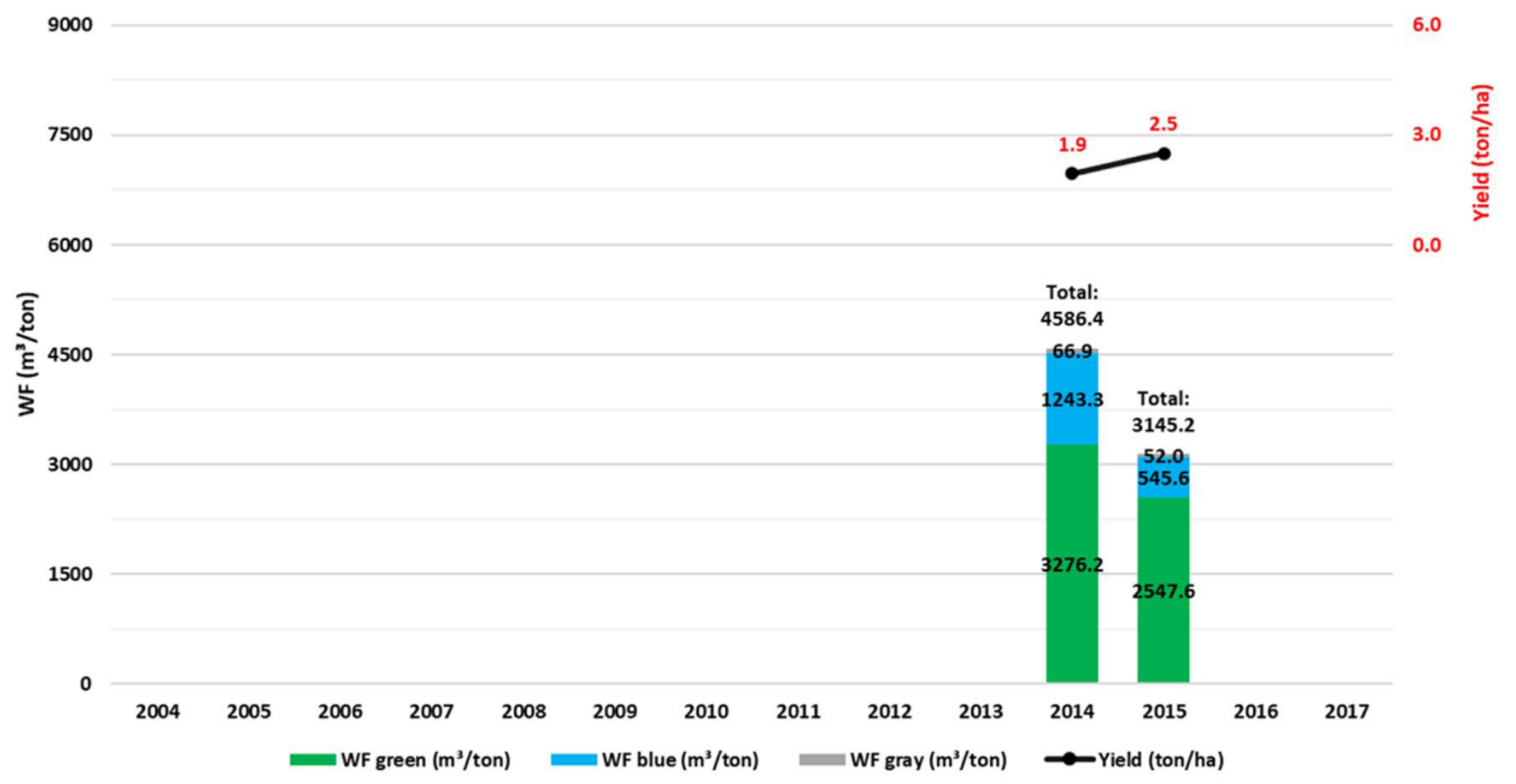

Figure 9. Groundnut water footprint, in São Carlos/SP, between 2004 and 2017. The green part of the graph represents the green water footprint $\left(\mathrm{WF}_{\text {green }}\right)$, the blue part represents the blue water footprint $\left(\mathrm{WF}_{\text {blue }}\right)$ and the gray part represents the gray water footprint $\left(\mathrm{WF}_{\text {grax }}\right)$. The sum of the three plots is the total water footprint $\left(\mathrm{WF}_{\text {total }}\right)$. The graph also shows the crop yield over the years. 
Table 6. Statistical test results. White cells indicate the null hypothesis confirmed while gray cells indicate the null hypothesis rejected. The p-value results are shown for each WF component.

\begin{tabular}{|c|c|c|c|c|c|}
\hline \multirow{3}{*}{ Crop } & \multirow{3}{*}{ WF component } & \multicolumn{4}{|c|}{ Statistical tests } \\
\hline & & \multirow{2}{*}{ Shapiro-Wilk } & \multicolumn{2}{|c|}{ Mann-Kendall } & \multirow{2}{*}{ T-Student } \\
\hline & & & Upward trend & Downward trend & \\
\hline \multirow[t]{4}{*}{1} & Green & $>0.1000$ & 0.1622 & 0.8377 & 0.0000 \\
\hline & Blue & $>0.1000$ & 0.4564 & 0.5436 & 0.0007 \\
\hline & Gray & $>0.1000$ & 0.3920 & 0.6080 & 0.0000 \\
\hline & Total & $>0.1000$ & 0.3712 & 0.6287 & 0.0000 \\
\hline \multirow[t]{4}{*}{2} & Green & 0.0270 & 0.7079 & 0.2920 & Not applied \\
\hline & Blue & $>0.1000$ & 0.9227 & 0.0773 & 0.0000 \\
\hline & Gray & $>0.1000$ & 0.8632 & 0.1368 & 0.0010 \\
\hline & Total & $>0.1000$ & 0.8632 & 0.1368 & 0.0003 \\
\hline \multirow[t]{4}{*}{3} & Green & 0.0230 & 0.6692 & 0.3307 & Not applied \\
\hline & Blue & $>0.1000$ & 0.4564 & 0.5436 & 0.0526 \\
\hline & Gray & $<0.0100$ & 0.6291 & 0.3709 & 0.0000 \\
\hline & Total & 0.0130 & 0.6692 & 0.3307 & Not applied \\
\hline \multirow[t]{4}{*}{4} & Green & $>0.1000$ & 0.7444 & 0.2556 & 0.0000 \\
\hline & Blue & $>0.1000$ & 0.9601 & 0.0399 & 0.0000 \\
\hline & Gray & 0.0270 & 0.9859 & 0.0140 & Not applied \\
\hline & Total & 0.0340 & 0.8858 & 0.1142 & Not applied \\
\hline \multirow[t]{4}{*}{5} & Green & $>0.1000$ & 0.9813 & 0.0187 & 0.0000 \\
\hline & Blue & 0.0440 & 0.1622 & 0.8378 & Not applied \\
\hline & Gray & $>0.1000$ & 0.9910 & 0.0090 & 0.0000 \\
\hline & Total & $>0.1000$ & 0.9601 & 0.0399 & 0.0000 \\
\hline \multirow[t]{4}{*}{6} & Green & $>0.1000$ & \multirow{4}{*}{\multicolumn{2}{|c|}{ Not applied }} & 0.0000 \\
\hline & Blue & 0.0550 & & & 0.0000 \\
\hline & Gray & $>0.1000$ & & & 0.0000 \\
\hline & Total & $>0.1000$ & & & 0.0000 \\
\hline \multirow[t]{4}{*}{7} & Green & $>0.1000$ & \multirow{4}{*}{\multicolumn{2}{|c|}{ Not applied }} & 0.0260 \\
\hline & Blue & $>0.1000$ & & & 0.0020 \\
\hline & Gray & $>0.1000$ & & & 0.0000 \\
\hline & Total & 0.0420 & & & Not applied \\
\hline
\end{tabular}

Crops: 1 = Sugarcane; 2 = Maize; $3=$ Soybean; $4=$ Tomato; $5=$ Cassava; $6=$ Rice; $7=$ Beans.

For the Shapiro-Wilk, with a significance level of 5\%, we observe the null hypothesis dominating the statistical test evaluation. From 28 water footprint components verified, 20 were confirmed as a sample of a normal population, with high p-values. We see different behavior in some WF components in maize (green), soybeans (green, gray and total), tomato (gray and total), cassava (blue) and beans (total), probably caused by local conditions. Considering this prevalence in the samples analyzed, we can accept a normality assumption for water footprint components. In this sense, this distribution can be used to predict the water footprint values of different cultures. A longer WF data series, considering local and global levels, could ensure this conclusion to all temporary crops.

Using the t-student test, applied in $21 \mathrm{WF}$ components, with a significance level of $5 \%$, we observe that the null hypothesis was rejected in 19. This indicates that most of the average results of our study are significantly different from global mean values defined by Mekonnen \& Hoekstra (2011). It makes clear how the water footprint can vary from a regional scale (sample) to a global mean value (population) (Brauman et al., 2013; Mekonnen \& Hoekstra, 2014). The difference between the study periods should also be considered in these results.

The results of the ANOVA and Tukey test were resumed in Table 5. In the same column, identical lower-case letters indicate no significant difference between the mean values of WF components, according to these tests. We note that the sugarcane, cassava and tomato crops showed a similarity in all WF components. These crops formed a group of low water use in this region, according to our results. Isolated similarities were found in each WF component, but we cannot make further conclusions on these results.

Considering the Mann-Kendall test results (Table 6), we observe the null hypothesis confirmation predominance. 
From $20 \mathrm{WF}$ components verified by the test, 15 presented no monotonic trend, with a significance level of $5 \%$. The exceptions were the blue and gray WF component of tomato; and blue, green and gray for cassava, all of them with a downward trend.

These results show how this indicator varies over time, in general, with no monotonic trend. This can be explained by the number of variables involved in calculating the water footprint and how they may change over time. Examples are human decisions linked to agricultural management and crop implementation, or climate variations, whose data are inserted into the CROPWAT model (Zhuo et al., 2014). All these variables input a high uncertainty in the WF calculation, which can reach values above 20\% (Zhuo et al., 2014; Elliott et al., 2014). Thus, it is difficult to expect a monotonic trend in this water use indicator.

\section{Correlation coefficients}

Table 7 summarizes the linear correlation coefficients, calculated between each WF component and the yields of each crop analyzed. As expected, the majority of the values are negative, as the yields are inversely proportional to WF components (Equations 1, 2, and 3). An exception was the relation of WF blue and beans yields. However, this result is not representative, once this crop yields changed only one time over the years (1.2 ton ha ${ }^{-1}$ in four of the five years analyzed), while $\mathrm{WF}_{\text {blue }}$ varied in a range of 1307.1 to $2820.8 \mathrm{~m}^{3}$ ton $^{-1}$. This outlier in yield data causes an interpretation problem in this result. Also, for this crop, we have few results that not allow many conclusions of this behavior. The same is valid for groundnut, where all coefficients were -1 , because of the low amount of data (only 2 years).

Considering the coefficients between crop yields, $\mathrm{WF}_{\text {green }}$ and, $\mathrm{WF}_{\text {gray }}$, we can see how elevated yields are important to reduce these components. In both cases, six out of eight crops presented correlation coefficients from -0.75 to -1 , which indicate a strong negative relationship between the two variables correlated. In general lines, for $\mathrm{WF}_{\text {green, }}$ this correlation result can indicate that the crop is well adapted to the local rainfall regime. For $\mathrm{WF}_{\text {gray }}$, this strong negative correlation can indicate that yield is not of additional fertilizer use. Thus, natural conditions are favorable for these temporary crops in São Carlos. Nevertheless, it is important to compare WF results with other regions to confirm these evidences and to completely observe how good is the use of water in a region.
For the correlation coefficients between yields and $\mathrm{WF}_{\mathrm{blue}}$, six out of eight crops have correlation coefficients less than -0.5 , resulting in a weak negative relationship between the variables. Possibly, more irrigation can be a favorable factor to raise yield rates for some temporary crops, once the coefficients values tend to be close or bigger than to zero. Also, using optimal development conditions, with no water restriction, the blue components values were overestimated, what approximated the coefficients values to zero, far from the tendency expected.

\section{CONCLUSIONS}

Here, we presented water footprint values of the temporary crops, produced in São Carlos, Brazil, between 2004 and 2017. This study was developed considering two aspects: a lack of water footprint studies in Brazil at a municipal level; and the absence of WF temporal evaluation, regarding data behavior and disparity causes.

Considering the crops evaluated in this study, sugarcane, a predominant crop in São Paulo state, presented low water footprint total average values $\left(166.2 \mathrm{~m}^{3}\right.$ ton $\left.^{-1}\right)$ when compared to the literature, because of the high local yield, and good adaptation in the region. Tomatoes showed good results compared to the global values in all the years evaluated. This indicates that sugarcane and tomatoes are favorable for cultivation in the São Carlos region. On the other hand, rice and groundnut crops demonstrate high water footprint variations, compared to world averages. This may indicate the inadequacy of these crops in the region.

In general terms, the statistical tests show that WF components do not follow a monotonic trend, either upward or downward. The tests also indicated that data can follow a normal distribution, and the results from local studies can be significantly different from global values. Correlation coefficients between yields and each water footprint components were strongly negative for $\mathrm{WF}_{\text {green }}$ and $\mathrm{WF}_{\text {gray }}$, indicating that the crop productivity is important to reduce the water use in these components and also that the natural conditions are favorable to the reduction of these components. The behavior for $\mathrm{WF}_{\text {blue }}$ was not the same, probably because of the less important influence of irrigation in crop yield and also because of modeling assumptions (no water restriction).

These conclusions can be useful for future studies. First, they emphasize the importance of WF evaluation at the municipality, using local data, when available, as global values cannot be effective to represent all regions. Also, stochastic simulations and future

Table 7. Correlation coefficients between water footprint components and crop yield.

\begin{tabular}{ccccc}
\hline Crop & $\rho\left(\mathbf{W F}_{\text {green }} x \gamma\right)$ & $\rho\left(\mathbf{W F}_{\text {blue }} \boldsymbol{x} \gamma\right)$ & $\rho\left(\mathbf{W F}_{\text {gray }} x \gamma\right)$ & $\rho\left(\mathbf{W F}_{\text {total }} x \gamma\right)$ \\
\hline 1. Sugarcane & -0.1791 & -0.3779 & -0.9998 & -0.6924 \\
2. Maize & -0.9260 & -0.6762 & -0.9445 & -0.9250 \\
3. Soybeans & -0.9202 & -0.4496 & -0.9592 & -0.9409 \\
4. Tomato & -0.5618 & -0.2873 & -0.4544 & -0.4938 \\
5. Cassava & -0.9328 & -0.1027 & -0.9974 & -0.9091 \\
6. Rice & -0.7767 & -0.7372 & -0.9947 & -0.9360 \\
7. Beans & -0.8877 & +0.4652 & -1.0000 & -0.9648 \\
8. Groundnut & -1.0000 & -1.0000 & -1.0000 & -1.0000 \\
\hline
\end{tabular}

$\mathrm{WF}_{\text {green }}$ : green water footprint; $\mathrm{WF}_{\text {blue }}$ : blue water footprint; $\mathrm{WF}_{\text {gray }}$ : gray water footprint; $\gamma$ : crop yield. 
previsions can be made, considering the statistical distribution we confirmed in this study.

The WF values may contain uncertainties because of the assumptions that are made. So, it is important to analyze the results carefully. In our study, we noted that the use of CROPWAT model, with an optimal development condition, can overestimate $\mathrm{WF}_{\text {blue }}$, being a source of bias for this component. But this approach can be useful for a first approximation in areas with no detailed information about irrigation schedule. We also point out uncertainties linked to crop variables, which can change according to the geographic, economic and cultural aspects. Some examples are the choices made by farmers, which are linked to agricultural crop management, new methods and technology applications and possible market opportunities (i.e. good prices). All these factors can influence the type of crop that will be planted in a region, and consequently, the water use.

Water footprint estimation can be important to evaluate the water used by agriculture, considering water and food security aspects. These values can be used as indicators for the conservation and conscious use of water resources. We expect to encourage another WF studies in Brazil, at local scale, as this concept is not properly explored in our country. Finally, the results from this study could be used as a first reference for other studies in regions with similar characteristics, in terms of climate and crops produced.

\section{ACKNOWLEDGEMENTS}

This study was financed in part by the National Council for Scientific and Technological Development - CNPq (grant number 165004/2018-5), by the Coordination of Improvement of Higher Education Personnel - CAPES (Finance Code 001 - grant number 88882.328917/2019-01) and by the São Paulo Research Foundation - FAPESP (grant number 2015/03806-1).

\section{REFERENCES}

Aldaya, M. M., \& Hoekstra, A. Y. (2010). The water needed for Italians to eat pasta and pizza. Agricultural Systems, 103(6), 351-360. http://dx.doi.org/10.1016/j.agsy.2010.03.004.

Allen, R. G., Pereira, L. S., Raes, D., \& Smith, M. (1998). Crop evapotranspiration: guidelines for computing crop water requirements (FAO Irrigation and Drainage Paper, No. 56). Rome: FAO.

Alvares, C. A., Stape, J. L., Sentelhas, P. C., Gonçalves, J. L. M., \& Sparovek, G. (2014). Koppen's climate classification map for Brazil. Meteorologische Zeitschrift, 22(6), 711-728. http://dx.doi. org/10.1127/0941-2948/2013/0507.

Anache, J. A. A., Wendland, E., Rosalem, L. M. P., Youlton, C., \& Oliveira, P. T. S. (2019). Hydrological trade-offs due to different land covers and land uses in the Brazilian Cerrado. Hydrology and Earth System Sciences, 23(3), 1263-1279. http://dx.doi.org/10.5194/ hess-23-1263-2019.
Bouman, B. A. M., Humphreys, E., Tuong, T. P., Barker, R., \& Donald, L. S. (2007). Rice and water (Advances in Agronomy, pp. 187-237). Boston: Academic Press.

Brasil. Ministério do Meio Ambiente. (2005, 18 de março). Resolução CONAMA n $^{\circ}$ 357/2005, de 17 de março de 2005. Dispõe sobre a classificação dos corpos de água e diretrizes ambientais para o seu enquadramento, bem como estabelece as condições e padrões de lançamento de efluentes, e dá outras providências. Diário Oficial [da] República Federativa do Brasil, Brasília.

Brauman, K., Siebert, S., \& Foley, J. (2013). Improvements in crop water productivity increase water sustainability and food security: a global analysis. Environmental Research Letters, 8(2), 024030. http:/ / dx.doi.org/10.1088/1748-9326/8/2/024030.

Bulsink, F., Hoekstra, A. Y., \& Booij, M. J. (2010). The water footprint of Indonesian provinces related to the consumption of crop products. Hydrology and Earth System Sciences Discussions, 6(4), 5115-5137. http://dx.doi.org/10.5194/hessd-6-5115-2009.

Burt, T. P., \& McDonnell, J. J. (2015). Whither field hydrology? The need for discovery science and outrageous hydrological hypotheses. Water Resources Research, 51(8), 5919-5928. http:// dx.doi.org/10.1002/2014WR016839.

Cabrera, M. C. M., Anache, J. A. A., Youlton, C., \& Wendland, E. (2016). Performance of evaporation estimation methods compared with standard 20 m-2 tank. Revista Brasileira de Engenharia Agricola e Ambiental, 20(10), 874-879. http://dx.doi.org/10.1590/18071929/agriambi.v20n10p874-879.

Chapagain, A. K., \& Hoekstra, A. Y. (2011). The blue, green and grey water footprint of rice from production and consumption perspectives. Ecological Economics, 70(4), 749-758. http://dx.doi. org/10.1016/j.ecolecon.2010.11.012.

Chapagain, A. K., Hoekstra, A. Y., Savenije, H. H. G., \& Gautam, R. (2006). The water footprint of cotton consumption: an assessment of the impact of worldwide consumption of cotton products on the water resources in the cotton producing countries. Ecological Economics, 60(1), 186-203. http://dx.doi.org/10.1016/j. ecolecon.2005.11.027.

Chapagain, A. K., \& Orr, S. (2009). An improved water footprint methodology linking global consumption to local water resources: a case of Spanish tomatoes. Journal of Environmental Management, 90(2), 1219-1228. PMid:18703270. http://dx.doi.org/10.1016/j. jenvman.2008.06.006.

Companhia Nacional de Abastecimento - CONAB. (2019a). Calendário de plantio e colheita de grãos no Brasil. Retrieved in 2019, March 15, from http://www.conab.gov.br

Companhia Nacional de Abastecimento - CONAB. (2019b). Acompanhamento da safra brasileira de grãos: mensal. Retrieved in 2019, March 15, from http://www.conab.gov.br 
Elliott, J., Deryng, D., Müller, C., Frieler, K., Konzmann, M., Gerten, D., Glotter, M., Flörke, M., Wada, Y., Best, N., Eisner, S., Fekete, B. M., Folberth, C., Foster, I., Gosling, S. N., Haddeland, I., Khabarov, N., Ludwig, F., Masaki, Y., Olin, S., Rosenzweig, C., Ruane, A. C., Satoh, Y., Schmid, E., Stacke, T., Tang, Q., \& Wisser, D. (2014). Constraints and potentials of future irrigation water availability on agricultural production under climate change. Proceedings of the National Academy of Sciences of the United States of America, 111(9), 3239-3244. PMid:24344283. http://dx.doi. org/10.1073/pnas.1222474110.

Empresa Brasileira de Pesquisa Agropecuária - EMBRAPA. (2019a). Cultivo de tomate para industrialização. Retrieved in 2019, January 15, from https://sistemasdeproducao.cnptia.embrapa. br/FontesHTML/Tomate/TomateIndustrial_2ed/plantio.htm

Empresa Brasileira de Pesquisa Agropecuária - EMBRAPA. (2019b). Produtividade do arroz. (Oryza sativa L.) e do feijão-comum (Phaseolus vulgaris L.) no Brasil, de 1985 a 2017. Retrieved in 2019, January 15, from http://www.cnpaf.embrapa.br/socioeconomia/ docs/arroz/produtividadearrozefeijao.htm

Empresa Brasileira de Pesquisa Agropecuária - EMBRAPA. (2020a). Correção e adubação da cana-de-açucar. Retrieved in 2020, April 15, from https://www.agencia.cnptia.embrapa.br/gestor/ cana-de-acucar/arvore/CONTAG01_6_711200516715.html

Empresa Brasileira de Pesquisa Agropecuária - EMBRAPA. (2020b). Adubação mineral (nitrogênio) do milho. Retrieved in 2020, April 15, from https://www.agencia.cnptia.embrapa.br/gestor/ milho/arvore/CONTAG01_47_168200511159.html

Empresa Brasileira de Pesquisa Agropecuária - EMBRAPA. (2020c). Fixação biológica de nitrogênio na cultura da soja na Região do Cerrado. Retrieved in 2020, April 15, from https:/ / www.embrapa.br/ busca-de-solucoes-tecnologicas/-/produto-servico/2394/ fixacaobiologica-de-nitrogenio-na-cultura-da-soja-na-regiao-do-cerrado

Empresa Brasileira de Pesquisa Agropecuária - EMBRAPA. (2020d). Cultivo da mandioca: adubação. Retrieved in 2020, April 15, from https://sistemasdeproducao.cnptia.embrapa.br/FontesHTML/ Mandioca/mandioca_amapa/adubacao.htm

Empresa Brasileira de Pesquisa Agropecuária - EMBRAPA. (2020e). Fertilização do solo (arroz). Retrieved in 2020, April 15, from https://www.agencia.cnptia.embrapa.br/gestor/arroz/arvore/ CONT000fessmgy502wx5eo0y53mhyvcjcebf.html

Empresa Brasileira de Pesquisa Agropecuária - EMBRAPA. (2020f). Adubação (feijão). Retrieved in 2020, April 15, from https:/ / www.agencia. cnptia.embrapa.br/Repositorio/CONTAG01_81_1311200215104. html

Empresa Brasileira de Pesquisa Agropecuária - EMBRAPA. (2020g). Sistemas de produção Embrapa: sistema de produção de amendoim: fertilizaçãa $e$ adubação. Retrieved in 2020, April 15, from https://www.spo. cnptia.embrapa.br/conteudo?p_p_id=conteudoportlet_WAR_si stemasdeproducaolf6_1ga1 ceportlet\&p_p_lifecycle=0\&p_P_ state $=$ normal\&p_p_mode $=$ view\&p_p_col_id $=$ column-1\&p_p_ col_count=1\&p_r_p_-76293187_sistemaProducaoId=3803\&p_ r_p_-996514994_topicoId $=3450$

Food and Agriculture Organization - FAO. (2019). ETc - Single crop coefficient $\left(K_{c}\right)$. Retrieved in 2019, January 15, from http:/ / www. fao.org/docrep/X0490E/x0490e0b.htm

Gerbens-Leenes, W., \& Hoekstra, A. Y. (2012). The water footprint of sweeteners and bio-ethanol. Environment International, 40(1), 202-211. PMid:21802146. http://dx.doi.org/10.1016/j. envint.2011.06.006.

Hoekstra, A. Y. (2003). Virtual water trade: Proceedings of the International Expert Meeting on Virtual Water Trade (Value of Water Research Report Series, No. 12). Delft: UNESCO-IHE.

Hoekstra, A. Y., Chapagain, A. K., Aldaya, M. M., \& Mekonnen, M. M. (2011). The water footprint assessment manual: setting the global standard. London: Earthscan.

Hoekstra, A. Y., \& Mekonnen, M. M. (2016). Imported water risk: the case of the UK. Environmental Research Letters, 11, 055002. https://doi.org/10.1088/1748-9326/11/5/055002

Instituto Brasileiro de Geografia e Estatística - IBGE. (2018). Produção agrícola municipal: série histórica. Retrieved in 2018, December 15, from http:// https://cidades.ibge.gov.br/brasil/sp/sao-carlos/

Kendall, M. A., \& Stuart, A. (1967). The advanced theory of statistics (2nd ed.). London: Charles Griffin.

Kongboon, R., \& Sampattagul, S. (2012). The water footprint of sugarcane and cassava in northern Thailand. Procedia: Social and Behavioral Sciences, 40, 451-460. http://dx.doi.org/10.1016/j. sbspro.2012.03.215.

Liu, C., Kroeze, C., Hoekstra, A. Y., \& Gerbens-Leenes, W. (2012). Past and future trends in grey water footprints of anthropogenic nitrogen and phosphorus inputs to major world rivers. Ecological Indicators, 18, 42-49. http://dx.doi.org/10.1016/j.ecolind.2011.10.005.

Lopez, L. I. F., \& Bautista-Capetillo, C. (2015). Green and blue water footprint accounting for dry beans (Phaseolus vulgaris) in primary region of Mexico. Sustainability, 7(3), 3001-3016. http:// dx.doi.org/10.3390/su7033001.

Lovarelli, D., Bacenetti, J., \& Fiala, M. (2016). Water Footprint of crop productions: a review. The Science of the Total Environment, 548-549, 236-251. PMid:26802352. http://dx.doi.org/10.1016/j. scitotenv.2016.01.022.

Mann, H. B. (1945). Non-parametric tests against trend. Econometrica, 13(3), 245-259. http://dx.doi.org/10.2307/1907187.

Mekonnen, M. M., \& Hoekstra, A. Y. (2011). The green, blue and grey water footprint of crops and derived crop products. 
Hydrology and Earth System Sciences, 15(5), 1577-1600. http:/ /dx.doi. org/10.5194/hess-15-1577-2011.

Mekonnen, M. M., Pahlow, M., Aldaya, M. M., Zarate, E., \& Hoekstra, A. Y. (2015). Sustainability, efficiency and equitability of water consumption and pollution in Latin America and the Caribbean. Sustainability, 7(2), 2086-2112. http://dx.doi.org/10.3390/ su7022086.

Mendes, I. C., Reis Júnior, F. B., Hungria, M., Sousa, D. M. G., Campo, R. J., Aguiar, J. L. P., \& Sousa, T. C. R. (2007). Adubação nitrogenada suplementar na soja cultivada em latossolos de cerrado (Boletim de Pesquisa e Desenvolvimento, No. 187). Embrapa Cerrados.

Mekonnen, M. M., \& Hoekstra, A. Y. (2014). Water footprint benchmarks for crop production: a first global assessment. Ecological Indicators, 46, 214-223. http://dx.doi.org/10.1016/j. ecolind.2014.06.013.

Organisation for Economic Co-operation and Development-OECD. (2019). Water use in agriculture. Retrieved in 2019, January 15, from http:/ /www.oecd.org/agriculture/water-use-in-agriculture.htm

Rinaldi, M., Ventrella, D., \& Gagliano, C. (2006). Comparison of nitrogen and irrigation strategies in tomato using CROPGRO model: a case study from southern Italy. Agricultural Water Management, 87(1), 91-105. http://dx.doi.org/10.1016/j.agwat.2006.06.006.

Santos, R. C., Freire, R. M., \& Suassuna, T. M. F. (2009). Amendoim: o produtorpergunta, a Embrapa responde. Brasília: Embrapa Informação Tecnológica.

São Carlos. (2019). A cidade de São Carlos. Retrieved in 2019, January 15, from http://www.saocarlos.sp.gov.br/index.php/conhecasao-carlos/115268-a-cidade-de-sao-carlos.html

Scarpare, F. V., Hernandes, T. A. D., Ruiz-Corrêa, S. T., Kolln, O. T., Gava, G. J. C., Santos, L. N. S., \& Victoria, R. L. (2016). Sugarcane water footprint under different management practices in Brazil: Tietê/Jacaré watershed assessment. Journal of Cleaner Production, 112, 4576-4584. http://dx.doi.org/10.1016/j.jclepro.2015.05.107.
Silva, V., Oliveira, S., Hoekstra, A., Dantas Neto, J., Campos, J., Braga, C., Araújo, L., Aleixo, D., Brito, J., Souza, M., \& Holanda, R. (2016). Water footprint and virtual water trade of Brazil. Water, 8(11), 517. http://dx.doi.org/10.3390/w8110517.

Vanham, D. (2013). An assessment of the virtual water balance for agricultural products in EU river basins. Water Resources and Industry, 1-2, 49-59. http://dx.doi.org/10.1016/j.wri.2013.03.002.

Zhang, Y., Zhang, J., Tang, G., Chen, M., \& Wang, L. (2016). Virtual water flows in the international trade of agricultural products of China. The Science of the Total Environment, 557-558, 1-11. PMid:26994788. http://dx.doi.org/10.1016/j.scitotenv.2016.02.166.

Zhuo, L., Mekonnen, M. M., \& Hoekstra, A. Y. (2014). Sensitivity and uncertainty in crop water footprint accounting: a case study for the Yellow River basin. Hydrology and Earth System Sciences, 18(6), 2219-2234. http://dx.doi.org/10.5194/hess-18-2219-2014.

\section{Authors contributions}

Alan Reis: Worked on the conceptualization, methodology, data curation, formal analysis, visualization and writing - original draft paper.

Alessandra Campos dos Santos: Worked on the conceptualization, methodology, data curation, formal analysis, visualization and writing - original draft paper.

Jamil Alexandre Ayach Anache: Worked on formal analysis, supervision and writing - review and editing.

Eduardo Mario Mendiondo: Was responsible for the supervision, project administration, and funding acquisition.

Edson Cezar Wendland: Was responsible for the supervision, project administration, and funding acquisition. 